\title{
CARBON-DISC 1.0 - A coupled, process-based model of global in- stream carbon biogeochemistry
}

Wim J. van Hoek ${ }^{1}$, Lauriane Vilmin ${ }^{1}$, Arthur H.W. Beusen ${ }^{1,2}$, José M. Mogollón ${ }^{4}$, Xiaochen Liu ${ }^{1}$, Joep J. Langeveld $^{1}$, Alexander F. Bouwman ${ }^{1,2,3}$, Jack J. Middelburg ${ }^{1}$

51 Department of Earth Sciences, Utrecht University, P.O. Box 80021, 3508TA Utrecht, the Netherlands. 2 PBL Netherlands Environmental Assessment Agency, P.O. Box 30314, 2500GH the Hague, the Netherlands.

3 Laboratory of Marine Chemistry Theory and Technology, Ministry of Education, Ocean University of China, Qingdao 266100, PR China.

4 Department of Industrial Ecology, Leiden University, P.O. Box 9518, 2300RA Leiden, the Netherlands.

\begin{abstract}
Here, we present the implementation of the freshwater carbon (C) cycle in the Dynamic In-stream Chemistry module (CARBON-DISC), which is part of the Integrated Model to Assess the Global Environment-Dynamic Global Nutrient Model

15 (IMAGE-DGNM). A coupled hydrology-biogeochemistry approach with 0.5 by 0.5 -degree resolution accounts for the spatial and temporal variability in dynamic conditions in the aquatic continuum using independent global databases. This processbased model resolves the concentrations, transformations and transfer fluxes of dissolved inorganic carbon (DIC), dissolved organic carbon $(D O C)$ and terrestrial and autochthonous particulate organic carbon $(P O C)$ from headwaters to river mouth with a time step of 1 month for the period 1950-2000.
\end{abstract}

This is a major step forward in basin scale modelling of the $\mathrm{C}$ processing in freshwater systems, since simulated results can be validated at every location and point in time, and the model can be applied for retrodiction and to analyse future scenarios. Validation of the model with long-term measurement data shows a fair agreement, considering that this is a global model. To analyse the performance of the full production-respiration DISC module, two other schemes are presented, including an abiotic system excluding any in-stream processing of DOC and allochthonous production, and an extended abiotic system including heterotrophic respiration, but excluding production. Furthermore, a sensitivity analysis shows that many parameters, such as temperature, solar radiation, organic sediment mineralization rate and $\mathrm{C}$ inputs, including particulate organic carbon from terrestrial vegetation and dissolved inorganic carbon from groundwater, strongly affect atmosphere-freshwater exchange of $\mathrm{CO}_{2}$. 
https://doi.org/10.5194/gmd-2019-205

Preprint. Discussion started: 17 September 2019

(c) Author(s) 2019. CC BY 4.0 License.

(c) (i)

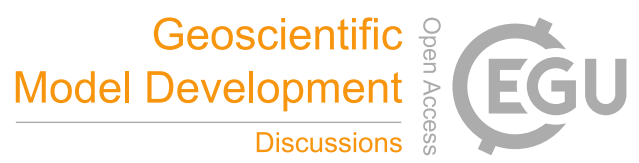

\section{Introduction}

Only recently, (Cole et al., 2007) identified rivers as significant components of the global carbon (C) cycle and recognized that river systems function as globally important sources of $\mathrm{CO}_{2}$. Since then, multiple studies have confirmed the significance of freshwater systems in global carbon cycling, but there is substantial uncertainty on the magnitude of fluxes and the human perturbation (Cole et al., 2007; Battin et al., 2009; Tranvik et al., 2009; Bastviken et al., 2011; Raymond et al., 2013; Regnier et al., 2013; Borges et al., 2015; Holgerson and Raymond, 2016; Sawakuchi et al., 2017).

40 Carbon in freshwater originates from terrestrial (allochthonous) sources and from aquatic within system (autochthonous) production (Prairie and Cole, 2009). Allochthonous $\mathrm{C}$ is delivered to surface water as dissolved or particulate organic C (plant litter, leached material) or dissolved inorganic C (carbonates produced during weathering or soil respiration) (Cole et al., 2007). After delivery to streams, rivers, lakes or reservoirs, organic $C$ is metabolized to inorganic carbon, buried in sediment or laterally transported towards oceans. The inorganic carbon delivered or generated within the system is transported

45 downstream or emitted to the atmosphere as $\mathrm{CO}_{2}$ since aquatic systems are predominantly supersaturated in $\mathrm{CO}_{2}$ relative to the atmosphere (Kempe, 1984; Frankignoulle et al., 1998; Duarte and Prairie, 2005)

Many studies have been published on local C processing in headwaters, rivers, lakes, reservoirs and floodplains (Tranvik et al., 2009; Crawford et al., 2013, 2016; Wallin et al., 2013; Hotchkiss et al., 2015; Wollheim et al., 2015; Holgerson and

50 Raymond, 2016). These local assessments have identified the key governing processes and their sensitivity to perturbations. Global assessments of riverine carbon cycling, and in particular $\mathrm{CO}_{2}$ partial pressure and global $\mathrm{CO}_{2}$ effluxes have been very important to quantify the role of rivers in the global $\mathrm{C}$ cycle. However, these budgeting approaches fail to describe the rapid changes in the global C-cycle (Ciais et al., 2013)and are not appropriate for retrodictions (predictions of the past) or making informed projections. Many existing river biogeochemistry models lack spatio-temporal input and hydrological constraints.

55 Moreover the models usually lump the various compartment of the aquatic continuum and regress modelled and observed $\mathrm{C}$ export at the scale of whole river basins (Beusen et al., 2005; Mayorga et al., 2010; Kroeze et al., 2012) After upscaling, such approaches yield a first order quantification of $\mathrm{C}$ fluxes to the coastal ocean. However, they contribute little to advance our understanding of the $\mathrm{C}$ cycle in river basins. To describe the interactions between land-use changes, interventions in the hydrology (dam construction, reservoirs, water extraction), and wastewater discharge, and their consequences for riverine $\mathrm{C}$ cycling, we need a model that spatio-temporally resolves the biogeochemical processes coupled to hydrology.

In this paper we present the implementation of freshwater C cycling in the Dynamic In-stream Chemistry module (CARBONDISC), which is part of the Integrated Model to Assess the Global Environment (IMAGE (Stehfest et al., 2014)) Dynamic Global Nutrient Model (IMAGE-DGNM (Vilmin et al., 2019)). This new model is specifically designed for global applications 
https://doi.org/10.5194/gmd-2019-205

Preprint. Discussion started: 17 September 2019

(c) Author(s) 2019. CC BY 4.0 License.

(c) (i)

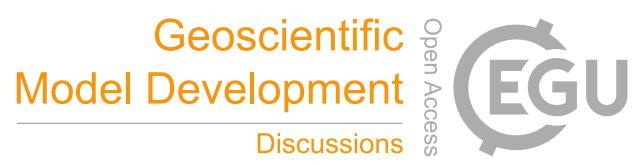

65 and describes the spatial and temporal variability of carbon concentration and fluxes based on the river basin hydrology from headwaters to mouth and carbon cycling processes. Here, we present the main features of the CARBON-DISC module, we apply the module in the stream network of the Rhine basin and evaluate its characteristics with a sensitivity analysis.

\section{Model and data used}

\subsection{General aspects}

70 The IMAGE-DGNM model framework integrates the PCR-GLOBWB dynamic global hydrology model (Sutanudjaja et al., 2018 ) with the IMAGE model (Stehfest et al., 2014) that provides $\mathrm{C}$, nitrogen $(\mathrm{N})$ and phosphorus $(\mathrm{P})$ delivery to inland waters (streams, rivers, lakes, reservoirs, floodplains) for the period 1900-2000. The biogeochemistry within the streams, rivers, lakes, reservoirs and floodplains is modelled using the DISC module, which is part of the IMAGE-DGNM framework (Vilmin et al., 2019). The IMAGE-DGNM has a global coverage with a 0.5 degree spatial resolution and includes spatially resolved

75 biogeochemical input data ((Beusen et al., 2015); (Vilmin et al., 2019)). IMAGE-DGNM uses ancillary information of air temperature from a CRU dataset (Mitchell and Jones, 2005) as a 1:1 proxy for the water temperature. Although the temporal scale of the model framework is adjustable, here we focus on monthly-scale processes.

IMAGE provides land cover data to PCR-GLOBWB and wastewater, suspended particulate matter (SPM) and allochthonous 80 organic carbon loads to CARBON-DISC; PCR-GLOBWB provides water flows, depth and volume of water bodies for streams of Strahler order $>5$. The hydrology for smaller streams and rivers is parameterized in IMAGE-DGNM using the approach proposed by (Wollheim et al., 2008), as described in Beusen et al., 2015 (Fig. 1). DGNM explicitly accounts for spatiotemporal distribution of sources for the different forms of $\mathrm{C}$. These include wastewater, erosion, weathering, vegetation in riparian areas and floodplains (details are provided in Table 1). After delivery of $\mathrm{C}$ in the form of particulate organic carbon

85 (POC), dissolved organic carbon (DOC), dissolved inorganic carbon (DIC, the sum of $\mathrm{CO}_{2}, \mathrm{HCO}_{3}{ }^{-}$and $\mathrm{CO}_{3}{ }^{2-}$ ) and alkalinity $(A L K)$ to streams and rivers (see Table 1), the DISC model calculates in-stream biogeochemistry and transport from Strahler order 1 to the mainstream for each grid cell, and from upstream cells to the coastal ocean. 


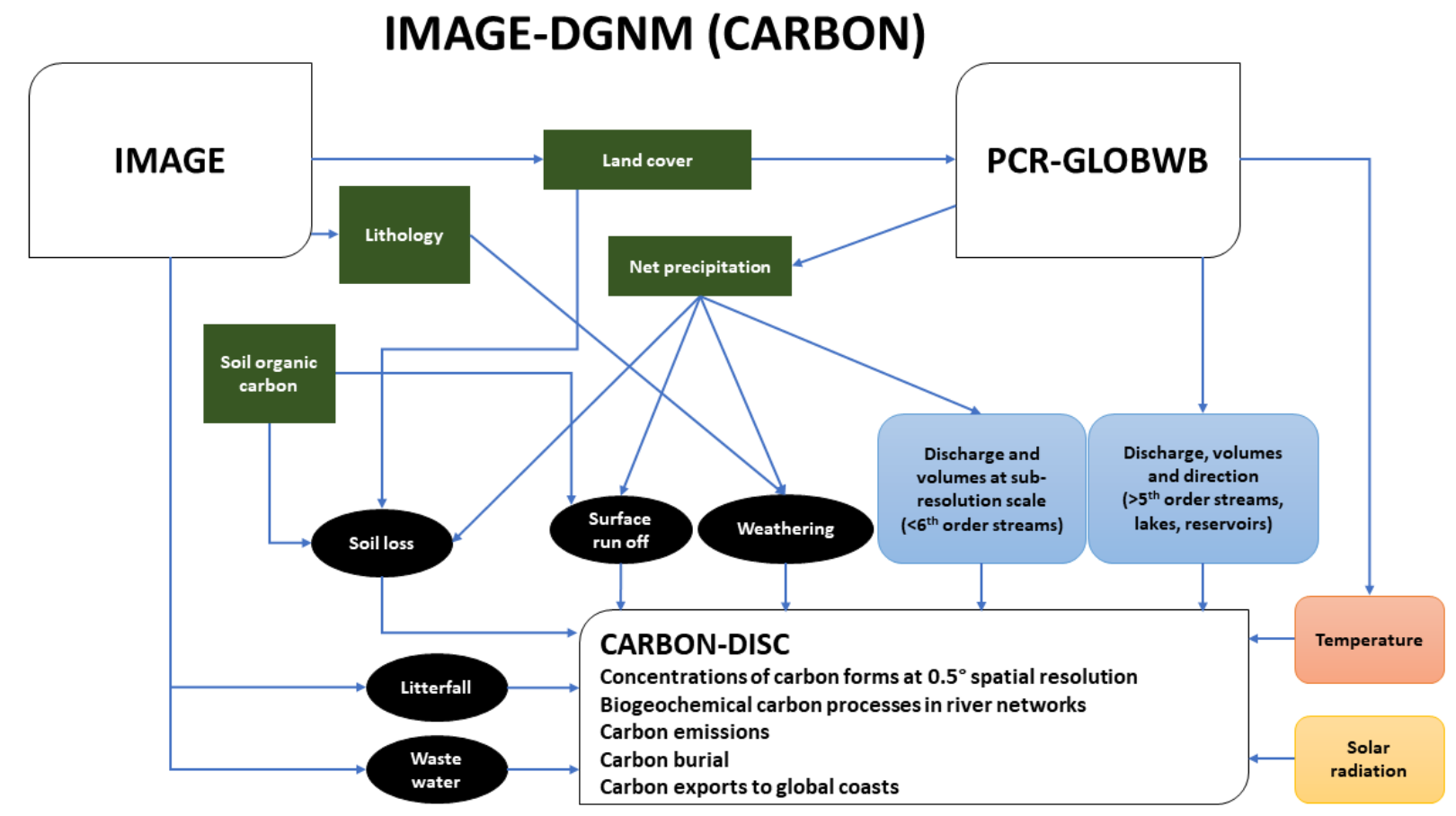

Figure 1: Scheme of the IMAGE-DGNM framework including CARBON-DISC for the in-stream biogeochemical carbon processes

IMAGE-DGNM explicitly resolves the mass and fluxes of suspended particulate matter ( $S P M)$ and sedimented particles. The pool of sedimented particles represents the mass of particles that have settled that can be resuspended as a result of exposure of the sediment surface to flowing waters. SPM is an important factor for light attenuation in the water column. (Kirk, 2011). $S P M$ is delivered from land to surface waters through soil erosion and from litterfall by terrestrial vegetation and during transport, it is produced within the water column through primary production. SPM consists of non-reactive, particulate inorganic matter $(P I M)$ and reactive particles, particulate organic matter $(P O M)$. All suspended particulate species also exist in the sediment form. Calcium carbonate particles are not identified as a distinct unit.

The CARBON-DISC module describes the biogeochemical transformations of DOC and POC to DIC. These instream processes depend on hydrology, temperature and solar irradiance (Fig. 1). POC comprises hundreds of different compounds varying from easily decomposable to recalcitrant (Middelburg, 1989; Bianchi, 2011). To account for the diversity in POC reactivity, we distinguish among allochthonous, terrestrial POC (POC terre and $\left.S E D O C_{\text {terre }}\right)$ and aquatic, autochthonous $P O C$ $\left(P O C_{a u t o}\right.$ and $\left.S E D O C_{\text {auto }}\right)$, because the mineralization of terrestrial organic matter with structural carbohydrates and lignins is slower than that of aquatic organic matter, rich in $\mathrm{N}$ and $\mathrm{P}$ (Middelburg, 2019). Physical dynamics of POC are governed by simplified deposition and resuspension equations. 
Alkalinity $(A L K)$ is generated by weathering of soils and rocks and delivered to streams. Although $A L K$ is the sum of excess bases in solution in natural environments carbonate alkalinity $\left(\mathrm{HCO}_{3}{ }^{-}+2 \mathrm{CO}_{3}{ }^{2-}\right)$ tends to make up most of the total alkalinity. In our model $A L K$ is delivered to surface water and combined with model generated $D I C$ to calculate $\mathrm{pCO}_{2}$ and $\mathrm{pH}$, but it is not modified by chemical reactions within the river. Consequently, CARBON-DISC ignores $A L K$ production and consumption by primary production, respiration, nitrification and calcium carbonate precipitation and dissolution within the stream network (Soetaert et al., 2007), since we assume that large scale alkalinity concentrations are governed by weathering of soils and rocks.

The performance of the model is validated by comparing simulation results of $D I C, A L K, \mathrm{pCO}_{2}, \mathrm{pH}, D O C$ and $T O C$ with literature data along the main stream (Fig. 2). Literature data were acquired from the GLORICH database (Hartmann et al.,

115 2014) (https://www.geo.uni-hamburg.de/en/geologie/forschung/geochemie/glorich.html). We compare monthly simulations and two weekly measurements of $D I C$, alkalinity, $\mathrm{pCO}_{2}, \mathrm{pH}, D O C$ and $\mathrm{TOC}$ for the station in Lobith, located on the German-Dutch border. The model can simulate at any temporal resolution, but here we discuss the monthly aggregated results.

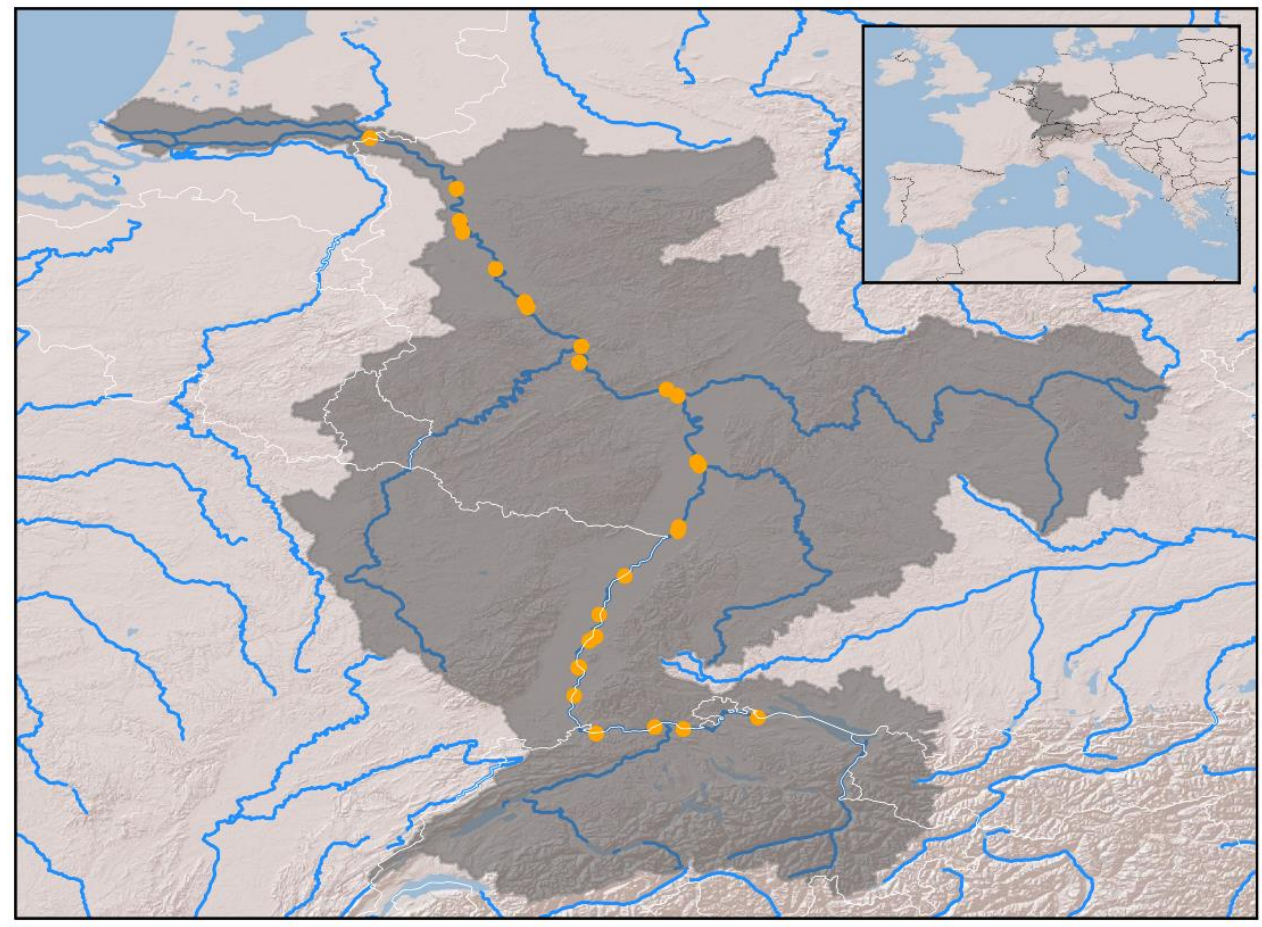

Figure 2: Map of Rhine basin with available in-stream carbon measurement locations for GLORICH (Hartmann et al., 2014) 


\subsection{Model description}

CARBON-DISC provides the concentration of any $\mathrm{C}$ species $i\left[\mathrm{Mmol} / \mathrm{km}^{3}\right]$ in each waterbody (i.e. a stream, lake, reservoir or floodplain) in each grid cell and for each time step (here 1 month) by calculating the total (tot) change in Mmol per time step of all C species $i$ in each waterbody (i.e. a stream, lake, reservoir or floodplain) in each grid cell, as an effect of biogeochemical (bgc) interactions between $\mathrm{C}$ species and as a result of hydrological (hyd) transport from waterbody to waterbody, within a grid cell as well as from grid cell to grid cell, as follows:

130

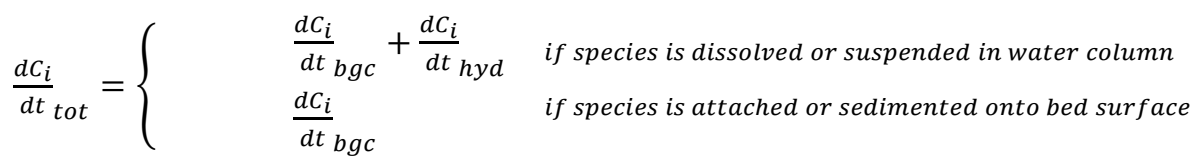

Hydrological advection of any dissolved or particulate $\mathrm{C}$ species $i$ in the water column, being DIC, DOC, POC and $A L G$, is calculated as follows:

$135{\frac{d C_{i}}{d t}}_{\text {hyd }}=L_{i}-Q *\left[C_{i}\right]$

with $L_{i}$ representing the upstream load [Mmol/yr] of species C $i . Q$ represents the water discharge $\left[\mathrm{km}^{3} / \mathrm{yr}\right]$ and $\left[C_{i}\right]$ represents the concentration of carbon species $i\left[\mathrm{Mmol} / \mathrm{km}^{3}\right]$, which we obtain from dividing the total amount of species $i[\mathrm{Mmol}]$ in the water body by the volume $\left[\mathrm{km}^{3}\right]$ of that water body (acquired from hydrological model data). From $1^{\text {st }}$ to $5^{\text {th }}$ Strahler orders, discharge and water volumes are calculated through the approach proposed by (Wollheim et al., 2008), as described in Vilmin

140 et al. (submitted). For $6^{\text {th }}$ Strahler order and higher, discharge and water body dimensions as well as floodplain area and depth data are provided by PCR-GLOBWB (Sutanudjaja et al., 2018) at a $0.5^{\circ}$ spatial resolution. Floodplains are only exchanging water with the $6^{\text {th }}$ Strahler order and higher in the same grid cell, and we assume their flow velocity is $10 \%$ of the main stream velocity. Hydrological transport from low to higher Strahler orders, and from one grid cell to the next grid cell, is calculated as long as these species are in the surface water column. POC, when sedimented as SEDOC (see below in Eq. (18)) remains

145 where it is settled until it is resuspended. $A L G_{b e n t h}$ is not being transported downstream, as it is considered attached to the stream bed.

\subsubsection{DIC dynamics}

External input of DIC in the DISC module is from weathering (Table 1) and there is in-stream production of DIC through mineralization of organic carbon forms and respiring living biomass. DIC is consumed through primary production. Finally, $D I C$ is added to or removed from the water body in the form of $\mathrm{CO}_{2}$ as a result of atmospheric exchange: 
https://doi.org/10.5194/gmd-2019-205

Preprint. Discussion started: 17 September 2019

(c) Author(s) 2019. CC BY 4.0 License.

(c) (i)

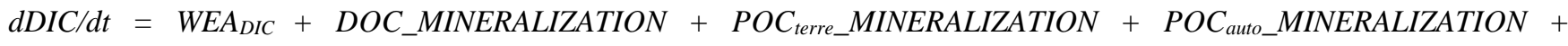

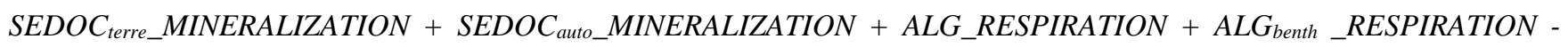

Atmospheric exchange is calculated from the difference in $\mathrm{CO}_{2}$ concentrations between the surface water and the atmosphere:

DIC_ATMOSPHERIC_EXCHANGE $=k_{\text {air }} *\left(\mathrm{CO}_{2 \text { water }}-\mathrm{CO}_{2 a t m o s p h e r e}\right)$

Where $\mathrm{CO}_{\text {2atmosphere }}$ is the atmospheric concentration, fixed at $0.0136 \mathrm{mmol} \mathrm{L}^{-1}$ (equivalent of $400 \mathrm{ppmv}$ ). $\mathrm{CO}_{2 \text { water }}$ is the dissolved $\mathrm{CO}_{2}$ concentration that is calculated (together with $\mathrm{pH}$ ) from $[D I C]\left[\mathrm{mmol} \mathrm{L}^{-1}\right],[A L K]\left[\mathrm{meq} \mathrm{L}^{-1}\right]$ and temperature with the MOCSY2.0 scheme from (Orr and Epitalon, 2015). Here, alkalinity delivery to surface waters is the same as DIC delivery, from $W E A_{D I C}$. Alkalinity is transported downstream without biogeochemical modifications. $k_{\text {air }}$ is the atmospheric exchange coefficient $\left[\mathrm{h}^{-1}\right]$ calculated as follows:

$k_{\text {air }}=k_{600} /\left(600 / S c_{T}\right)^{-0.5}$

where $k_{600}$ is the normalized $k_{\text {air }}$ at $20^{\circ} \mathrm{C}$ and $S c_{T}$ is the Schmidt number at temperature $T$ [C $\mathrm{C}^{\circ}$ (Wanninkhof, 2014), calculated from:

$S c_{T}=1911.1-118.11 T+3.4527 T^{2}-0.04132 T^{3}$

where $T$ is represented by air temperature (Mitchell and Jones, 2005). The atmospheric exchange coefficient $k_{600}$ can be estimated from flow velocity $\left(v\left[\mathrm{~cm} \mathrm{~s}^{-1}\right]\right)$ for small rivers or from windspeed $\left(\bar{u}_{10}\left[\mathrm{~m} \mathrm{~s}^{-1}\right]\right)$ for large rivers (Alin et al., 2011):

175

$k_{600}= \begin{cases}a_{1}+b_{1} \overline{\mathrm{u}}_{10} & \text { if stream width }>100 \text { meters } \\ a_{2}+b_{2} * v & \text { if stream width }<100 \text { meters }\end{cases}$

Values for $a_{1}, b_{1}, a_{2}$ and $b_{2}$ are by default set to respectively 4.46, 7.11, 13.82 and 0.35 (Alin et al., 2011).

$180 k_{\text {air }}$ above floodplains is strongly reduced with factor $F_{u 10_{\text {veg }}}(0.001)$ when (a fraction of $)$ high vegetation $\left(F_{\text {high_veg }}\right)$ covers the floodplain. Vegetation type data from IMAGE (Stehfest et al., 2014) was classified as either high or low vegetation. A spatial fraction of high vegetation $\left(F_{\text {high_veg }}\right)$ per 30 minutes gridcell was obtained from 5-minutes resolution IMAGE output. Equation (5a) is modified for floodplains as follows: 


\subsubsection{Organic carbon dynamics}

Surface runoff and waste water deliver DOC (Table 1), which is mineralized during its transport downstream. In-stream DOC production occurs through excretion by pelagic and benthic algae. $D O C$ is consumed by mineralization.

$P O C_{\text {terre }}$ has a terrestrial origin and originates from litterfall and soil erosion (Table 1). There is resuspension through in-stream erosion and sedimentation. Finally, $P O C_{\text {terre }}$ can be consumed by mineralization:

$P O C_{\text {auto }}$ is the autochthonous particulate organic carbon produced in-stream, via the death of primary producers. Similar to $P O C_{\text {terre, }}$, within river produced $\mathrm{POC}$ can be resuspended (erosion), deposited, or mineralized.

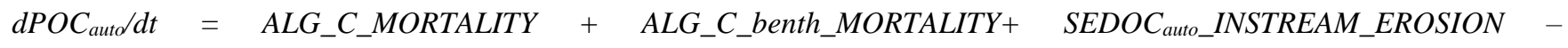

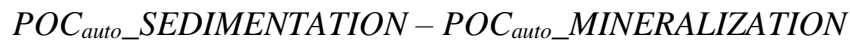

Particulate organic matter that has settled from the water column $\left(S E D O C_{\text {terre }}\right.$ and $S E D O C_{\text {auto }}$ ) can either be resuspended to the water column, transformed into DIC via mineralization or become buried.

The relevant equations are:

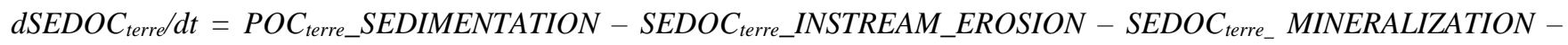
$S E D O C_{\text {terre__B }}$ BURIAL

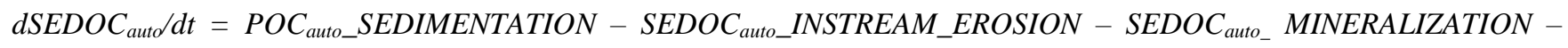
SEDOC auto_B $B U R I A L$

The erosion of the individual sedimented C species is a fraction of the total erosion $\Phi_{\text {ero_tot }}\left[\right.$ ton/yr]. $\Phi_{\text {ero_tot }}$ is calculated from the total mass of sediment in the water body $\left(S E D_{\text {tot }}[\right.$ ton] $)$, bedarea $\left(A\left[\mathrm{~km}^{2}\right]\right)$, flow velocity $(v[\mathrm{~km} / \mathrm{yr}])$, slope $\left(S\left[\mathrm{~km}^{*} \mathrm{~km}^{-1}\right]\right)$, 215 a fixed erosion coefficient $k_{\text {ero }}$ [ton $\left./ \mathrm{km}^{2}\right]$ of $2 * 10^{4}$ and a half-saturation constant $k_{\text {sed }}[\mathrm{km}]$ of $1 * 10^{-6}$ :

$\Phi_{\text {ero } \_ \text {tot }}=k_{\text {ero }} *\left(S E D_{\text {tot }} / A\right) /\left(k_{\text {sed }}+S E D_{\text {tot }} / A\right) * S * v * A$ 
https://doi.org/10.5194/gmd-2019-205

Preprint. Discussion started: 17 September 2019

(c) Author(s) 2019. CC BY 4.0 License.

(c) (1)

with:

$S E D_{\text {tot }}=S E D I M+S E D O M_{\text {terre }}+S E D O M_{\text {auto }}$

SEDIM represents the mass [ton] of sedimented inorganic matter and SEDOM $M_{\text {terre }}$ and SEDOMauto represent the masses [ton] of organic matter in the sediment of terrestrial and in-stream origin, respectively. Their masses are calculated from $S E D O C_{\text {terre }}$

and $S E D O C_{\text {auto }}$ as:

$S E D O M_{\text {terre }}=S E D O C_{\text {terre }} / \mathrm{f}_{\mathrm{C}_{-} \text {SEDOCterre }} * \mathrm{MM}_{\mathrm{C}}$

$S E D O M_{\text {auto }}=S E D O C_{\text {auto }} / \mathrm{f}_{\mathrm{C}_{-} S E D O C a u t o} * \mathrm{MM}_{\mathrm{C}}$

230 with $\mathrm{f}_{\mathrm{C}_{-} S E D O C \text { terre }}$ and $\mathrm{f}_{\mathrm{C}_{-} S E D O C a u t o}$ the mass fractions of $\mathrm{C}$ in $S E D O M_{\text {terre }}$ and $S E D O M_{\text {auto }}$ respectively, assumed to be 0.5 . $\mathrm{MM}_{\mathrm{C}}$ is the molar mass of $\mathrm{C}(12 \mathrm{~g} / \mathrm{mol})$.

To calculate erosion of individual particulate species we use:

$\Phi_{\text {ero_POCterre }}=\left(S E D O C_{\text {terre }} / S E D_{\text {tot }}\right) * \Phi_{\text {ero_tot }}$

$\Phi_{\text {ero_POCauto }}=\left(S E D O C_{\text {auto }} / S E D_{\text {tot }}\right) * \Phi_{\text {ero_tot }}$

Sedimentation of $P O C$ (terre and auto) is calculated with:

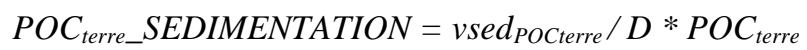

POC auto_SEDIMENTATION $=v_{\text {sed }}$ POCauto $/ D * P O C_{\text {auto }}$

where $v \operatorname{sed}_{P O C}$ is the sediment deposition velocity which is assumed to be $4.38\left[\mathrm{~km} \mathrm{yr}^{-1}\right]$ or $0.5 \mathrm{~m} \mathrm{~h}^{-1}$ (Vilmin et al., 2019) for both the terrestrial and autochthonous POC. $D$ is the stream depth $[\mathrm{km}]$.

The temperature-dependent mineralization rates for DOC, POC (terre and auto) and SEDOC (terre and auto) are formulated 245 as follows:

DOC_MINERALIZATION $=f_{\min }(T) * k_{D O C \min } * D O C$

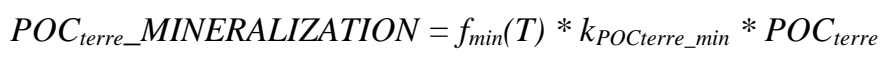

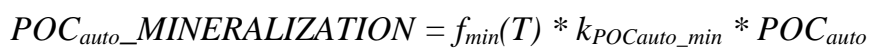

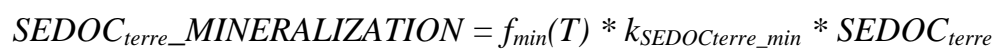

$S E D O C_{\text {auto_MINERALIZATION }}=f_{\min }(T) * k_{\text {SEDOCauto_min }} * S E D O C_{\text {auto }}$

The temperature dependency is described with a standard Q10 function: 
https://doi.org/10.5194/gmd-2019-205

Preprint. Discussion started: 17 September 2019

(c) Author(s) 2019. CC BY 4.0 License.

(c) (i)

$f_{\text {min }}(T)=\exp \left(\frac{T-T_{\text {ref }}}{10}\right) \ln (Q 10)$

with $\mathrm{T}_{\text {ref }}$ as $15^{\circ}$ Celsius and Q10 set to 2 for all non-living organic species (Soetaert and Herman, 2008).

Burial is calculated with:

$S E D O C_{\text {terre_}} B U R I A L=k_{\text {burial }} * S E D O C_{\text {terre }}$

$S E D O C_{\text {auto_ }} B U R I A L=k_{\text {burial }} * S E D O C_{\text {auto }}$

Burial only occurs when the $S E D_{\text {tot }}$ per bed area is more than $50 \mathrm{~kg} / \mathrm{m}^{2}$.

\subsubsection{Primary producers}

$A L G$ and $A L G_{b e n t h}$ represent carbon in suspended and stream-bed attached primary producers, respectively. Primary producer biomass increases through fixation of $D I C$ and decreases via respiration (to $D I C$ ), mortality (to $P O C_{\text {auto }}$ ) or excretion (to $D O C$ ):

$d A L G / d t=A L G \_P R I M A R Y \_P R O D U C T I O N-A L G \_R E S P I R A T I O N$ - ALG_MORTALITY - ALG_EXCRETION

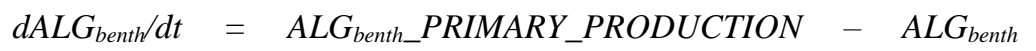

Primary production depends on the biomass of the producers, their maximal growth rates, temperature, and light and DIC availability. Similarly, respiration and excretion are modelled as a fraction of primary producer biomass and depend on temperature (standard Q10 functions, see Eq. (22)).

$A L G \_P R I M A R Y \_P R O D U C T I O N=f_{A L G \_p p}(T) * A L G_{I_{-} l i m} * A L G_{D I C \_l i m} * k_{A L G_{-} p p} * A L G$

$A L G_{\text {benth }} \_P R I M A R Y \_P R O D U C T I O N=f_{\text {ALGbenth_pp }}(T) * A L G_{\text {benth_I_lim }} * A L G_{\text {benth_DIC_lim }} * k_{A L G \text { Gbenth_pp }} * A L G_{b e n t h}$

275 ALG_RESPIRATION $=f_{\text {ALG_resp }}(T) * k_{A L G \_r e s p} * A L G_{-} C$

$A L G_{\text {benth_RESPIRATION }}=f_{\text {ALGbent__resp }}(T) * k_{\text {ALGbenth_resp }} * A L G_{\text {benth }}$

$A L G \_E X C R E T I O N=f_{A L G \_ \text {excr }}(T) * k_{A L G_{-} \text {excr }} * A L G$

$A L G_{\text {benth_EXCRETION }}=f_{\text {ALGbenth_excr }}(T) * k_{\text {ALGbent_excr }} * A L G_{\text {benth }}$

280 Mortality of $A L G$ and $A L G_{b e n t h}$ is attributed to viral lysis and modelled with a parasitic lysis factor ( $v f$ ) of 20 when a threshold concentration of $A L G$ and $A L G_{\text {benth }}$ of $19 \mu \mathrm{mol} \mathrm{C} \mathrm{L}{ }^{-1}\left(\approx 65 \mu \mathrm{g} \mathrm{L}^{-1} \mathrm{Chl}\right.$ a (Garnier et al., 2000)) is exceeded.

$A L G \_M O R T A L I T Y=\left(f_{A L G \_m o r t}(T) * k_{A L G_{-} m o r t}\right)+\left(f_{A L G \_ \text {mort }}(T) * k_{A L G_{-} m o r t}\right) *(1+v f) * A L G$

$A L G_{\text {benth_MORTALITY }}=\left(f_{\text {ALGbenth_mort }}(T) * k_{\text {ALGbenth_mort }}\right)+\left(f_{\text {ALGbenth_mort }}(T) * k_{A L G b e n t t_{\_} m o r t}\right) *(1+v f) * A L G_{\text {benth }}$ 
Primary production of $A L G$ and $A L G_{b e n t h}$ includes a DIC limitation (DIC_lim) term that is calculated with a Michaelis-Menten function as follows:

$A L G_{D I C_{-} \text {lim }}=\frac{[D I C]}{k_{D I C}+[D I C]}$

Light limitation for both pelagic and benthic primary producers is calculated using a spatial and temporal distribution of solar radiation reaching the surface of the water body and a water turbidity $\left(\eta_{t o t}\right)$ that affects light penetration through the water column. Cloudless average solar radiation per month of the year (MOY) per latitude (lat) is calculated by dividing the monthintegral solar radiation by the number of hours per month (HPM) as below:

$\mathrm{I}_{0}(\mathrm{MOY}, \mathrm{lat})=\frac{\int_{0}^{t} I_{0}(t, l a t) d t}{H P M}$

where $\mathrm{I}_{0}$, the solar radiation above the water surface, is integrated over time. Light limitation ( $I_{-}$lim) is calculated separately for benthic primary producers $\left(A L G_{b e n t h}\right)$ and for pelagic primary producers $(A L G)$. For the pelagic primary producers, limitation by light is integrated over the water column from water surface to the water body bottom at depth $z$, whereas for the benthic primary producers, production only takes place at the bottom, at depth $z$, of the water body. This is formulated as follows:

$I_{-} \lim (M O Y$, lat $)=\left\{\begin{array}{cl}\frac{I_{Z}}{\left(I_{Z}+k_{I_{A L G} C_{\text {benth }}}\right)} & \text { for } A L G_{\text {benth }} \\ \frac{\int_{0}^{Z} I_{0}(M O Y, \text { lat })}{\left(\int_{0}^{Z} I_{0}(M O Y, l a t)+k_{I_{A L G}}\right)} & \text { for } A L G\end{array}\right.$

with the light intensity $\mathrm{I}_{\mathrm{z}}$ at depth $z$ modelled using the Lambert-Beer equation:

$I_{z}=I_{0}(\mathrm{MOY}$, lat $) * e^{-\eta_{\text {tot }} * z}$

The turbidity $\eta_{t o t}$ is calculated by adding all contributions to light attenuation (Scheffer, 2004). The turbidity $\eta_{t o t}$, with

$\eta_{\text {water }}=0.8$ and $\eta_{P I M}=0.03$, is calculated according to:

$\eta_{\text {tot }}=\eta_{\text {water }}+\eta_{\text {POCterre }} *\left[\right.$ POC $\left._{\text {terre }}\right]+\eta_{\text {PoCauto }} *\left[P O C_{\text {auto }}\right]+\eta_{A L G} *[A L G]+\eta_{D O C} *[D O C]+\eta_{P I M} *[P I M]$

$\mathrm{I}_{0}$, represents the solar radiation above the water surface and is calculated according to:

$\mathrm{I}_{0}(\mathrm{t}$, lat $)=\theta_{\mathrm{s}}(\mathrm{t}$, lat $) * \mathrm{tt} * \mathrm{I}_{\text {solar_constant }}$

with $\theta_{\mathrm{s}}(\mathrm{t}$, lat) as the solar zenith angle. Zenith is the hemispheric point above the location of reference. Transmissivity (tt) is fixed at $0.8[-]$ and the solar constant ( $\left.\mathrm{I}_{\text {solar_constant }}\right)$ fixed at $1367 \mathrm{~W} \mathrm{~m}^{-2}$. 
https://doi.org/10.5194/gmd-2019-205

Preprint. Discussion started: 17 September 2019

(c) Author(s) 2019. CC BY 4.0 License.

(c) (i)

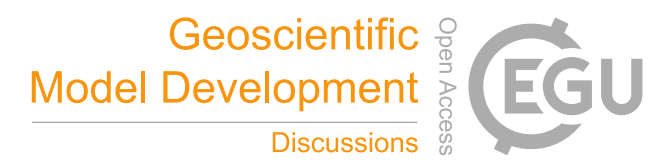

315 The solar zenith angle is calculated from:

$\theta_{\mathrm{s}}(\mathrm{t}$, lat $)=\arccos ((\sin ($ lat $) * \sin (\delta(\mathrm{t}))+\cos ($ lat $) * \cos (\delta(\mathrm{t})) * \cos (h(\mathrm{t}$, lat $)))$

with $\delta$ as the solar declination angle. The solar declination angle is the angle the sun makes with the Earth's equatorial plane. $h$ is the hour angle, which is the radian angle the earth has turned around, since the previous midnight at the location of reference at time $t$.

The solar declination is calculated as follows:

$\delta(\mathrm{t})=23.45 * \pi / 180 * \sin (2 \pi *(284+\mathrm{DOY}(\mathrm{t})) / 362.5)$

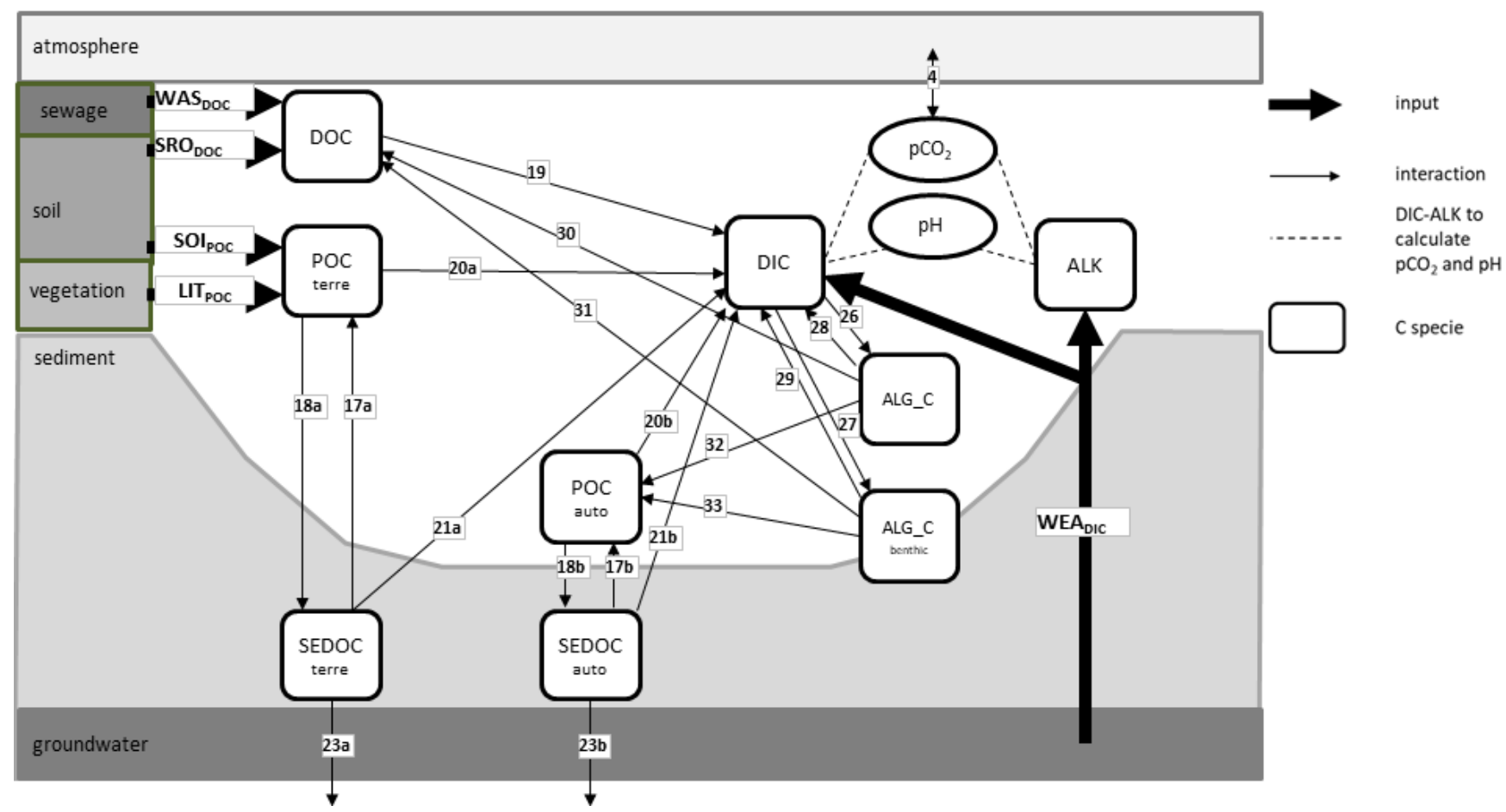

Figure 3: $\mathrm{C}$ forms, $\mathrm{C}$ sources and biogeochemical interactions in all simulated waterbodies. For clarity purposes, these schemes do not show the lateral influx and export. The numbers correspond to the equations in the text.

\subsection{Model and sensitivity analysis}

330 To analyse the performance of the full biology DISC model (Fig. 3), we present two other simplified in-stream C processing schemes: 
1) the abiotic reference, with only POC, DOC and DIC external sources, transport, and atmospheric $\mathrm{CO}_{2}$ exchange, and excluding any in-stream processing of DOC and production, mortality and mineralization of autochthonous C.

2) the respiration-only run, i.e. an extended abiotic system including respiration, but excluding autochthonous production. The numbers of the equations correspond with the numbers in Fig. 3.

Model parameter values and inputs are presented in Tables 2 and 3. The schemes of the abiotic and the respiration system respectively can be found in the supplementary material file.

Also, to further evaluate the model performance, we calculated the sensitivity of the modelled 5-year average (1995-2000) $\mathrm{CO}_{2}$ emissions, total carbon export and POC retention to the variation of 45 parameters, 8 environmental constraints and 8 carbon sources using Latin Hypercube Sampling (Saltelli, 2000). The method allows to quantify sensitivity of model outcomes to varying parameters values with a relatively limited number of runs. We ran the model 750 times with a uniformly 345 randomized combined set of all model parameters, external constraints and external inputs. In each run, each model parameter, constraint and input is randomly multiplied with a factor between 0.95 and 1.05 and combined into a setting for one run. For temperature, the randomization is applied between $-1 \mathrm{~K}$ and $+1 \mathrm{~K}$ of the default temperature. Values used for the parameters, constraints and inputs are presented in the supplementary material.

350 The contribution of each parameter $\left(X_{i}\right)$ to model outcome $Y$ is assessed with linear regression (Saltelli, 2000: in Beusen et al 2015):

$Y=\beta_{0}+\beta_{1} X_{1}+\beta_{2} X_{2} \ldots+\beta_{n} X_{n}+e$

355 with $\beta_{i}$ as the ordinary regression coefficient of parameter $i$ and $e$ the error of the approximation of $\mathrm{Y}$. The linear regression model can be evaluated for parameter contribution analysis if the coefficient of determination $\left(\mathrm{R}^{2}\right)$ is close to 1, i.e. when there is no variation of $\mathrm{Y}$ that is not explained with the linear regression model. A standardized regression coefficient $\left(S R C_{i}\right)$ is used to scale $\beta_{i}$ to the relative contribution of variation of $\mathrm{Y}$, by using the standard deviations of $X_{\mathrm{i}}$ and $Y$ as follows:

$360 S R C_{i}=\beta_{i} \frac{\sigma_{X_{i}}}{\sigma_{Y}}$

$S R C_{i}$ is independent of units and scale of parameters. The $S R C_{i}$ has a value between -1 and 1 . A positive $S R C_{i}$ value indicates that an increased parameter value leads to an increased output $Y$. A negative $S R C_{i}$ indicates a decreased output $Y$ with an increased parameter value. $S R C_{i}{ }^{2} / R^{2}$ yields the contribution of each parameter $X_{i}$ to model outcome $Y$. 


\section{Results}

The DISC module has been developed for global application, but, in this paper, we apply the model to the stream network of the Rhine basin without parameter tuning. The river Rhine drains an important part of Western Europe with an area of 185620 $\mathrm{km}^{2}$ and a length of $1250 \mathrm{~km}$ (van der Weijden and Middelburg, 1989). The annual average discharge is $2300 \mathrm{~m}^{3} / \mathrm{s}$. The hydrology of the Rhine is strongly impacted by dams. Furthermore, with a population of 58 million inhabitants, it drains strongly urbanized landscapes with intensive agricultural systems (Uehlinger et al., 2009). The river Rhine has been monitored over decades for a range of monitoring stations. We present the IMAGE-DGNM results for the period 1950-2000, with estimates of the carbon delivery, retention, biogeochemical transformation, export and emission to the atmosphere for the entire watershed.

\subsection{Carbon flows in the Rhine basin}

375 Irrespective of the complexity of the biological processing, the river Rhine represents a source of $\mathrm{CO}_{2}$ to the atmosphere (Fig. 4). In the abiotic scheme (Fig. 4(a)), $\mathrm{CO}_{2}$ emissions are very low (0.02 Tg C/yr), while emissions in the respiration-only scheme (Fig. 4(b)) and in the biological scheme (Fig. 4(c)) are 118 (2.36 Tg C/yr or 41\% of total C inputs) and 93 times higher (1.85 $\mathrm{Tg} \mathrm{C} / \mathrm{yr}$ or $32 \%$ of total $\mathrm{C}$ inputs), respectively. This indicates that outgassing of delivered $\mathrm{CO}_{2}$ from external sources is very limited compared to within system generation of $\mathrm{CO}_{2}$ by respiration. Furthermore, the difference between the respiration-only 380 and biology scheme with respect to the basin $\mathrm{CO}_{2}$ emissions suggests that in-stream biological processing is an important aspect in regulating $\mathrm{CO}_{2}$ emissions from the aquatic continuum. The export of $D I C$ is only $7 \%$ and $6 \%$ higher in the respirationonly $(1.35 \mathrm{Tg} / \mathrm{yr}$ or $+0.9 \mathrm{Tg} / \mathrm{yr})$ and biology scheme $(1.33 \mathrm{Tg} / \mathrm{yr}$ or $+0.7 \mathrm{Tg} / \mathrm{yr})$ respectively, than in the abiotic scheme $(1.26$ $\mathrm{Tg} / \mathrm{yr}$ ), while in-stream production of DIC is 2.42 and $3.71 \mathrm{Tg} \mathrm{C} / \mathrm{yr}$ for respectively the respiration and the biology scheme versus $0 \mathrm{Tg} \mathrm{C} / \mathrm{yr}$ in the abiotic scheme (Fig. 5). Nearly all $\mathrm{CO}_{2}$ that is produced and consumed through in-stream biogeochemistry is emitted to the atmosphere in both the respiration-only and the biology schemes. 


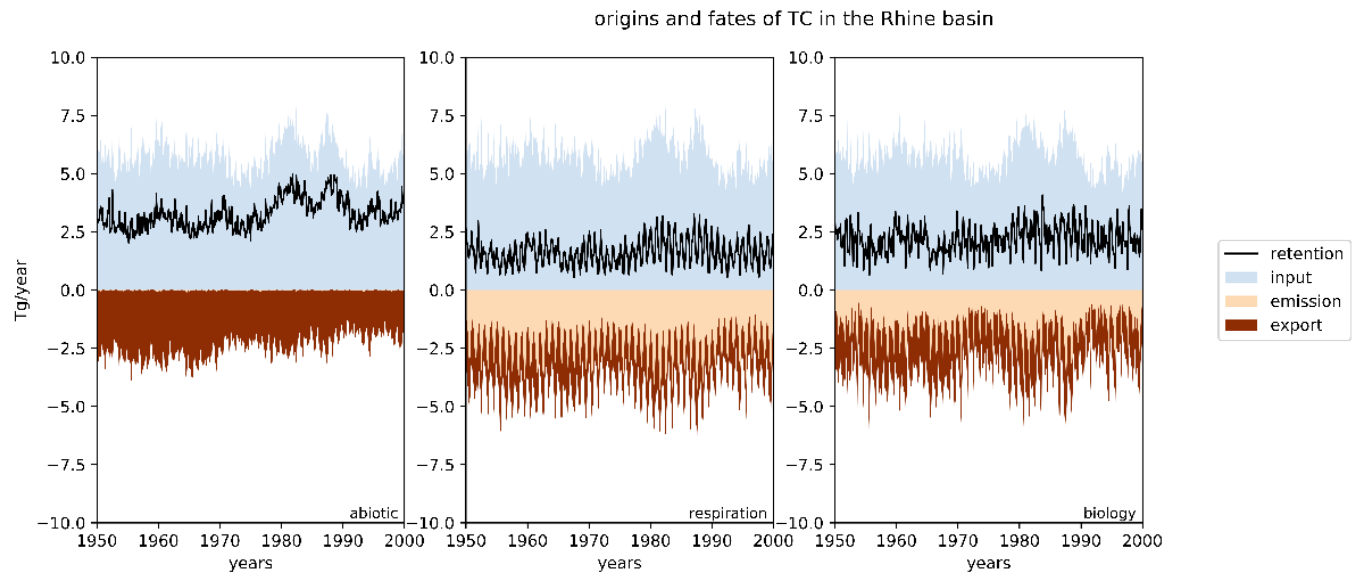

Figure 4: Time series of total basin aggregated carbon budget for the abiotic (a), respiration (b) and biology (c) schemes

In the abiotic scheme, about 3.25 $\mathrm{Tg} \mathrm{C} / \mathrm{yr}$ (57\%) is retained in the Rhine basin, while total $\mathrm{C}$ retention in the respiration-only and biological schemes is $1.66 \mathrm{Tg} / \mathrm{yr}$ (29\% of total C input) and $2.07 \mathrm{Tg} / \mathrm{yr}$ (36\% of total C input), respectively (Fig. 5). The difference in $\mathrm{C}$ retention between the respiration-only and the biology scheme implies that in-stream biological processing is a necessary element to consider when quantifying basin retention of carbon. Total carbon delivery is $5.8 \mathrm{Tg} / \mathrm{yr}$ in all schemes, but total $\mathrm{C}$ export to the ocean in the abiotic scheme is $2.48 \mathrm{Tg} / \mathrm{yr}$ ( $43 \%$ of total $\mathrm{C}$ input), and $1.78 \mathrm{Tg} / \mathrm{yr}$ ( $31 \%$ of total C input) and $1.88 \mathrm{Tg} / \mathrm{yr}$ (32\% of total $\mathrm{C}$ input) in the respiration and biology schemes, respectively.

DIC, DOC and $P O C_{\text {terre }}$ average inputs into freshwaters of the Rhine basin are 1.3, 0.96 and $3.51 \mathrm{Tg} / \mathrm{yr}$, or 23,17 and $60 \%$ of the total C input, respectively (Fig. 5). In the abiotic scheme, DOC delivery is fully balanced by export. In the respiration-only and biology schemes, $D O C$ delivered to the aquatic system is partly exported $(0.27 \mathrm{Tg} / \mathrm{yr}, 28 \%$ DOC of input, and $0.34 \mathrm{Tg} / \mathrm{yr}$, $35 \%$ DOC of input, respectively). In-stream removal of DOC through mineralization is $0.69 \mathrm{Tg} / \mathrm{yr}$ (72\% of DOC input) and $0.82 \mathrm{Tg} / \mathrm{yr}$ (85\% of input). In the biology scheme, an additional $0.2 \mathrm{Tg} / \mathrm{yr}$ ( $21 \%$ of $D O C$ input) of DOC is produced in-stream by algal excretion. Export of $D O C$ for the abiotic, respiration-only and biology schemes is $0.96,0.27$ and $0.34 \mathrm{Tg} / \mathrm{yr}$, respectively.

About $0.26 \mathrm{Tg} / \mathrm{yr}$ (7\% of $P O C$ input) of the $P O C$ delivered to the freshwater system (3.51 Tg/yr) is exported in the abiotic scheme. In the respiration-only and biology scheme, export of $P O C$ is $0.16 \mathrm{Tg} / \mathrm{yr}$ (5\% of $P O C$ input) and $0.2 \mathrm{Tg} / \mathrm{yr}(6 \%$ of POC input), respectively. For the biology scheme, $P O C$ includes $P O C_{\text {terre }}$ and $P O C_{\text {auto }}$. $P O C$ removal is $3.25 \mathrm{Tg} / \mathrm{yr}(93 \%$ of total $P O C$ input) in the abiotic scheme, and $3.35 \mathrm{Tg} / \mathrm{yr}$ (95\% of $P O C$ input) and $4.69 \mathrm{Tg} / \mathrm{yr}$ (134\% of $P O C$ input) in the respiration-only and full biology respectively. In-stream production of POC (1.38 Tg/yr) in the biology scheme through primary production results in a higher $P O C$ removal rate than $P O C$ input. 

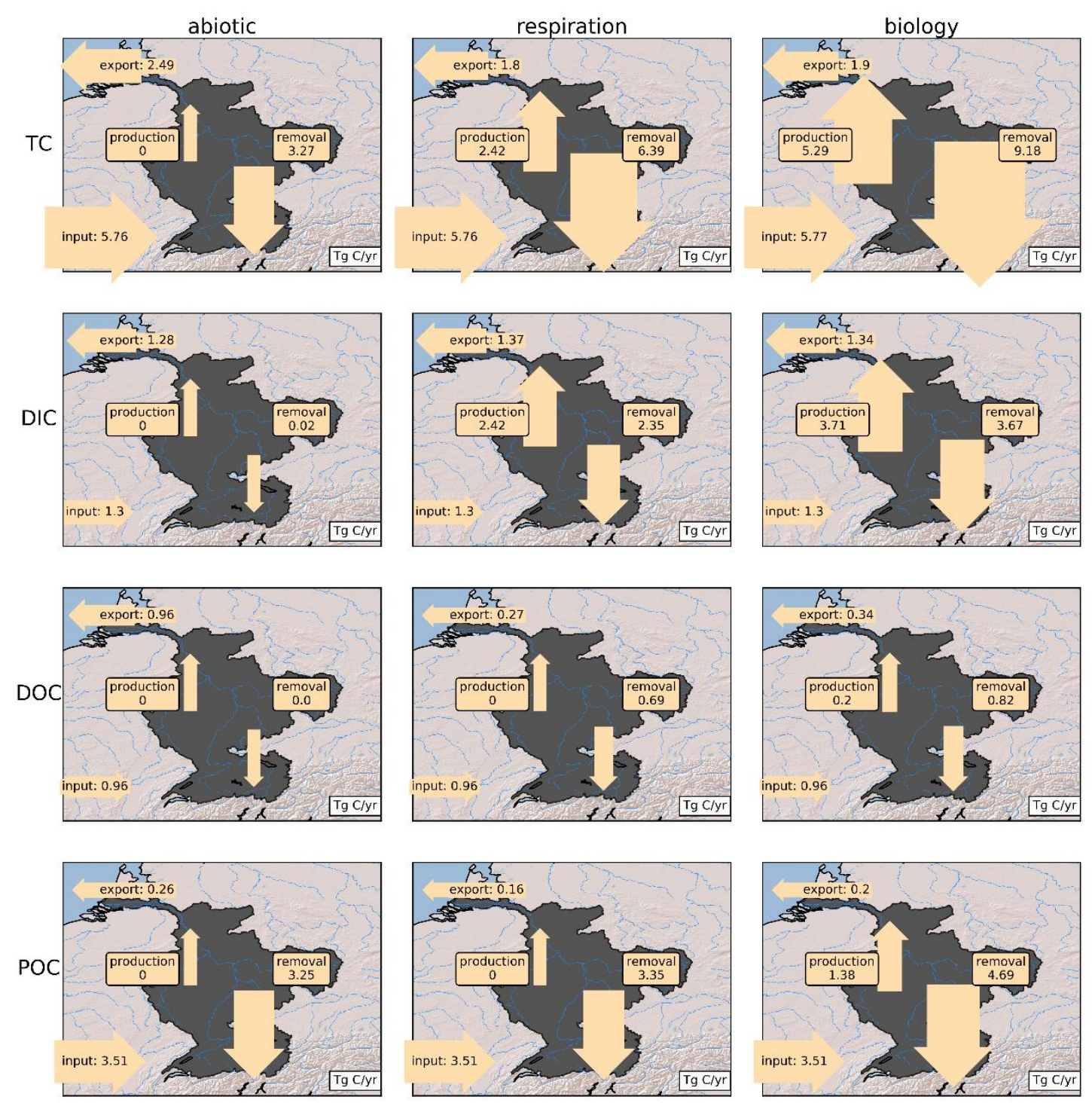

Figure 5: 50 year (1950-2000) average modelled input, production, removal and export fluxes of the Rhine basin of total carbon (TC) and $\mathrm{C}$ species for the three biogeochemical schemes (i.e., abiotic, respiration and biology).

\subsection{Validation}

Basin average DIC concentrations are higher by a few $\mathrm{mg} / \mathrm{L}$ in the respiration and biology scheme compared to the abiotic one, as an effect of in-stream production of DIC by respiration. Alkalinity concentrations are identical among the different schemes, since the imported bicarbonate is not biogeochemically active during its transport through the aquatic continuum. Simulated DIC and alkalinity concentrations in the biology scheme are on average respectively $46 \%$ and $43 \%$ lower than 
observations (Fig. 6(b) and 6(e)) and are also weakly correlated with measurements (bicarbonate $\mathrm{r}^{2}=0.01 ;$ DIC abiotic: $\mathrm{r}^{2}=0.05$; DIC respiration: $\mathrm{r}^{2}=0.07$; DIC biology: $\mathrm{r}^{2}=0.07$ ). The weak correlation is likely related to the parameterization of the riverine alkalinity flux (Jansen, 2010), which depends on the coarse spatial distribution of the lithology and riverine discharge. The lithological data (Dürr et al., 2005) used here show only the dominant lithological class in 0.5 by 0.5 -degree resolution.

425 Furthermore, runoff calculated by PCR-GLOBWB is prone to uncertainty and may be systematically underestimated in source areas of alkalinity.

Simulated average values of $\mathrm{pCO}_{2}$ in the respiration-only and biology schemes are high (Fig. 6(d): 1399 and 1183 ppm, respectively), but much lower than average values of $5261 \mathrm{ppm}$ from the GLORICH database. This underestimation can be partly attributed to underestimated DIC and alkalinity, but values based on indirect measurements may also be strongly biased (Abril et al., 2015). Moreover, direct $\mathrm{pCO}_{2}$ measurement in the Rhine using an equilibrator device vary from 545 to $1990 \mathrm{ppm}$ (Frankignoulle et al., 1998).

The average simulated abiotic (8.0), respiration-only (7.6) and biology (7.7) $\mathrm{pH}$ values (Fig. 6(a))] show a fairly good 435 agreement with average measurements $(\mathrm{pH}=7.6)$, with a low $\mathrm{r}^{2}$ for the abiotic run $\left(\mathrm{r}^{2}=0.04\right)$, and higher ones for the respiration and biology schemes $\left(\mathrm{r}^{2}=0.31\right.$ and $\mathrm{r}^{2}=0.29$ respectively). The simulated $D O C$ (Fig. 6(f)) and TOC (Fig. 6(c)) concentrations compare well with measurements (DOC [abiotic: $\mathrm{r}^{2}=0.73$; respiration: $\mathrm{r}^{2}=0.79$; biology: $\mathrm{r}^{2}=0.81$ ]; TOC [abiotic: $\mathrm{r}^{2}=0.88$; respiration: $\mathrm{r}^{2}=0.95$; biology: $\left.\mathrm{r}^{2}=0.95\right]$ ), with the abiotic scheme leading to overestimated TOC and DOC compared to measurements (DOC_measurements: $2.8 \mathrm{mg} / \mathrm{L}$. and DOC_abiotic: $7.4 \mathrm{mg} / \mathrm{L}$ [ $>159 \%$ ]; TOC_measurements: $3.6 \mathrm{mg} / \mathrm{L}$ and 440 TOC_abiotic: $14.3 \mathrm{mg} / \mathrm{L}$ [ $>297 \%]$ ) and the respiration and biology scheme underestimating DOC and TOC (DOC_respiration: $3.6 \mathrm{mg} / \mathrm{L}$ [>29\%] and DOC_biology: $3.7 \mathrm{mg} / \mathrm{L}$ [>31\%]; TOC_respiration: $8.8 \mathrm{mg} / \mathrm{L}$ [>144\%] and TOC_biology: $9.0 \mathrm{mg} / \mathrm{L}$ $[<150 \%])$. 
https://doi.org/10.5194/gmd-2019-205

Preprint. Discussion started: 17 September 2019

(c) Author(s) 2019. CC BY 4.0 License.

(c) (i)
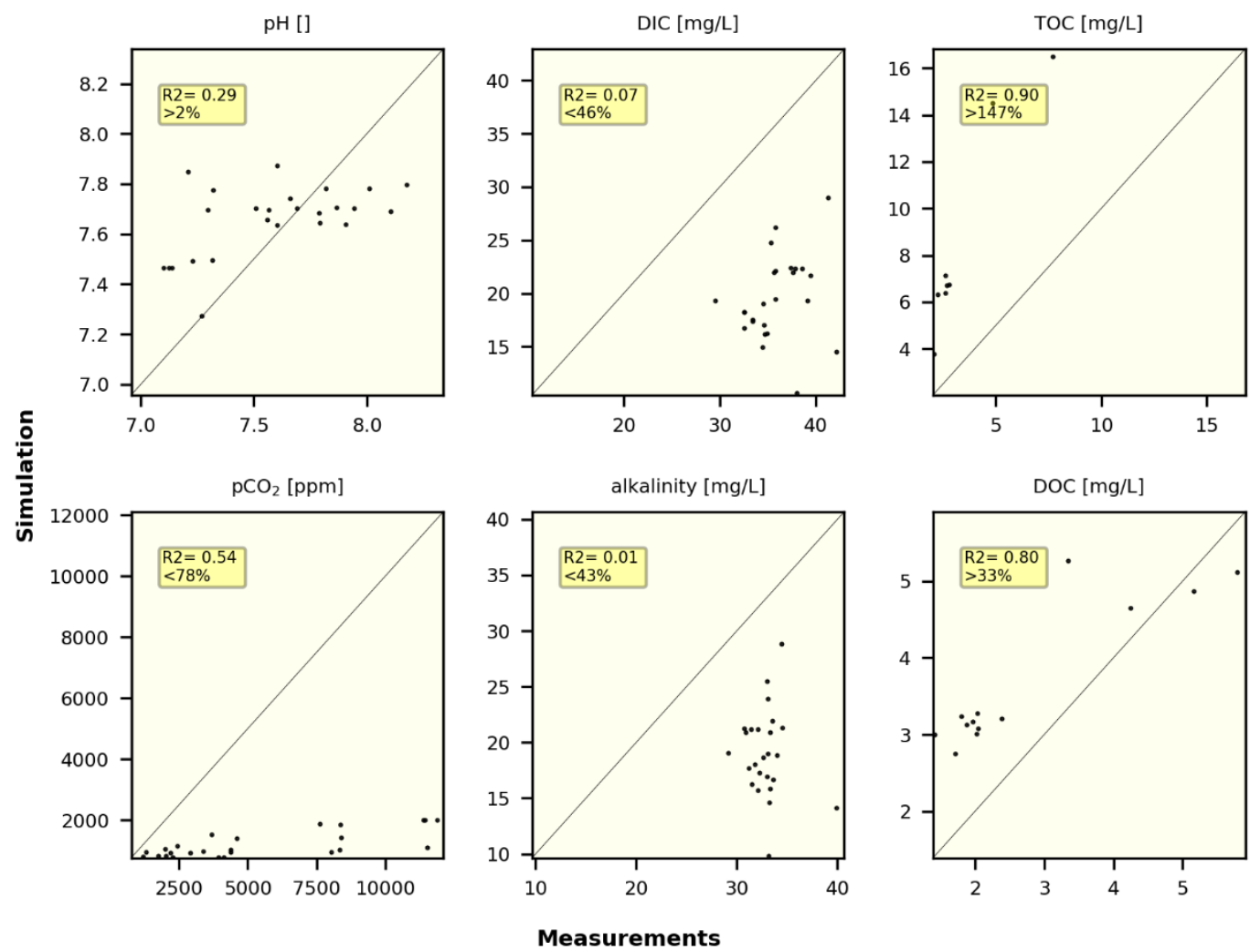

Figure 6: Comparison between average measurements ( $x$-axis) and average simulations (biology scheme) for all available stations in the Rhine basin. Measurements are from the GLORICH database (Hartmann et al., 2014)

Figure 7 shows a 50-year simulation (for the abiotic, respiration-only and biology schemes) and measurement time series for station Bimmen/Lobith at the German/Dutch border. Differences among simulation results of the different schemes are most apparent for the organic forms of carbon (DOC and TOC). In the abiotic simulations all delivered organic $\mathrm{C}$ remains organic and concentrations are high, whereas in the other two schemes, organic forms are mineralized to DIC, resulting in lower concentrations of organic forms and elevated $\mathrm{pCO}_{2}$. Time series of all other available measurement locations are found in the supplementary material section $\mathrm{E}$ (validation data). 


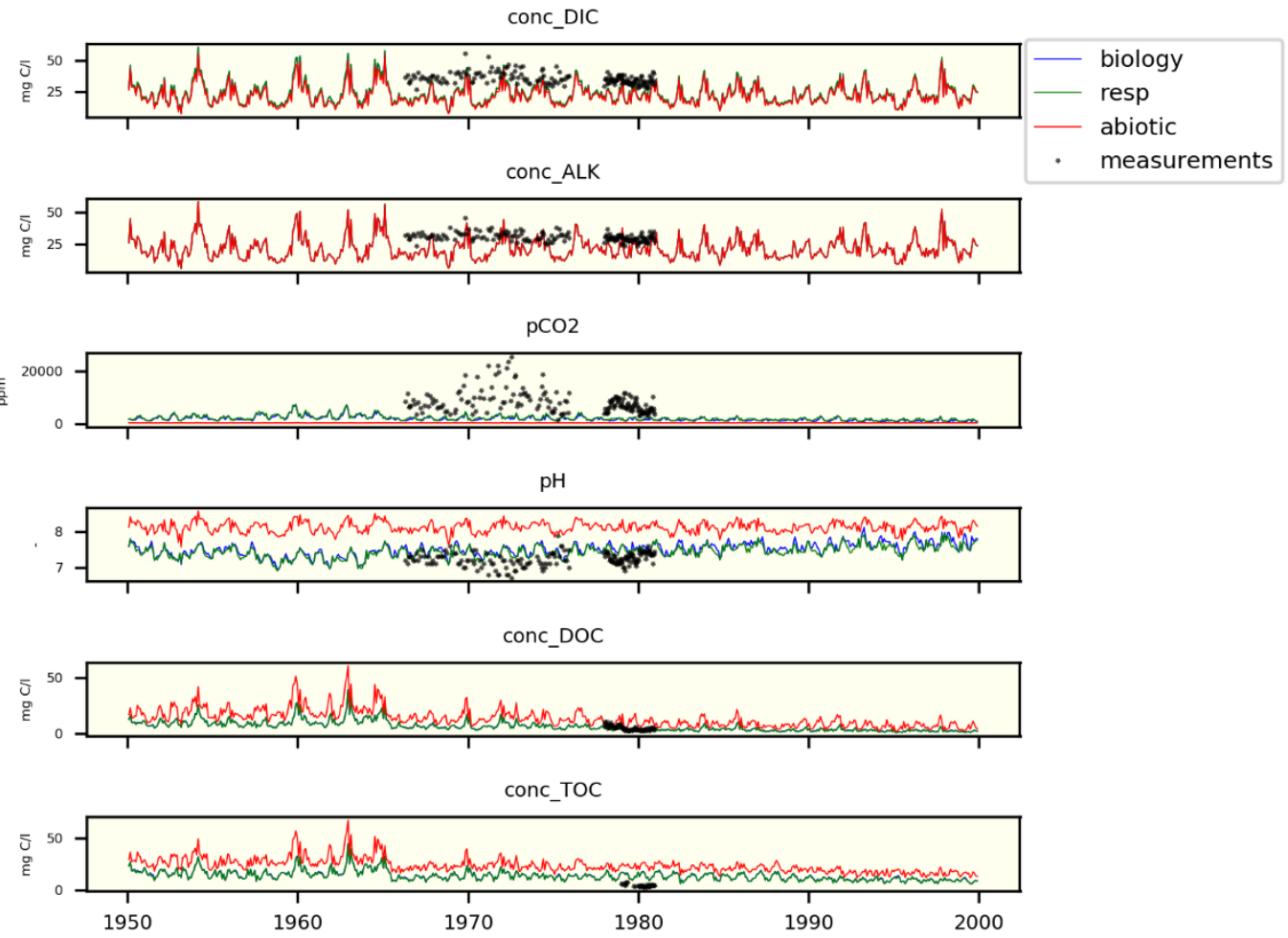

Figure 7: Timeseries of measurements and simulations at Bimmen/Lobith, Germany. Measurements are from the GLORICH database (Hartmann et al., 2014)

\subsection{Sensitivity analysis}

The influence of a range of parameters on simulated $\mathrm{CO}_{2}$ emissions, $\mathrm{C}$ export and $\mathrm{C}$ retention was investigated, but we discuss only those parameters that have an influence of more than $20 \%$ on the variation of simulated $\mathrm{CO}_{2}$ emissions, $\mathrm{C}$ export or $\mathrm{C}$ retention. Table 4 shows the most important outcomes of the sensitivity analysis. The entire table, containing all assessed parameters and SRC results is available in the supplementary materials section F (sensitivity analysis).

Simulated total basin $\mathrm{CO}_{2}$ emissions are strongly influenced by many model parameters. Total basin $\mathrm{CO}_{2}$ exchange is positively influenced by litter input in floodplains $(\mathrm{SRC}=0.45), \mathrm{DIC}$ fluxes from groundwater $(\mathrm{SRC}=0.43)$, the organic sediment mineralization rate $(\mathrm{SRC}=0.28)$ and temperature $(\mathrm{SRC}=0.27)$. The $\mathrm{CO}_{2}$ exchange is negatively influenced by alkalinity flux from groundwater $(\mathrm{SRC}=-0.42)$, global radiation $(\mathrm{SRC}=-0.24)$ and burial rate $(\mathrm{SRC}=-0.22)$. Except for the floodplains, $\mathrm{CO}_{2}$ emissions are largely governed by $D I C$ and $A L K$ inputs that originate from groundwater. $\mathrm{CO}_{2}$ emissions from floodplains are predominantly sensitive to temperature, global radiation, organic sediment mineralization rate, burial rate, minimum sediment thickness and most dominantly by input of POC from terrestrial vegetation. 
The sensitivity analysis shows that variability of total C export (of which DIC is the dominant C species) is almost entirely governed by variability of alkalinity delivery from groundwater, i.e. weathering $(\mathrm{SRC}=0.9)$. Almost all other carbon eventually escapes to the atmosphere.

The most important controlling factor of the modelled retention of $P O C_{\text {terre }}$ is the mineralization rate of $S E D O C_{\text {terre }}$, $k_{\text {SEDOCterremin, }}$ which is governed by temperature. More mineralization enables more $\mathrm{C}$ to escape from the system as DIC. As expected, the burial rate also strongly affects $P O C$ retention. Furthermore, an increased input of $P O C_{\text {terre }}$ from litterfall leads to an increased total retention fraction.

Many regression models use discharge as a driver of river C export at the river basin scale (Beusen et al., 2005; Mayorga et al., 2010; Kroeze et al., 2012; Strokal et al., 2016), our sensitivity analysis suggests that discharge has a minor direct influence on the $\mathrm{C}$ biogeochemistry, retention and emissions and only total $\mathrm{C}$ export was strongly influenced by discharge ( $\mathrm{SRC}=0.34)$. This concerns the river Rhine, and analysis of the results for other rivers is needed to assess if this is a general or local feature.

\section{Conclusions}

The DISC module of IMAGE-DGNM is a major step forward in basin scale modelling of river systems. For the first time, we are able to make an integral and systemic simulation of biogeochemical $\mathrm{C}$ processing on the river basin scale in fair agreement with observations. Results show that process-based modelling is essential to assess the fate of $\mathrm{C}$ in river basins. Biogeochemical production and consumption of $\mathrm{C}$ within its lifetime in the river basin are in the same order of magnitude as the inputs. The sensitivity analysis showed that in-stream chemistry and $\mathrm{CO}_{2}$ emissions are weakly correlated with discharge in contrast to recent regression approaches. The dominant driver of total $\mathrm{C}$ export, being mainly $D I C$ export, is the weathering input from groundwater. $\mathrm{CO}_{2}$ emissions are strongly responsive to temperature variability and $P O C$ dynamics. The sensitivity analysis also suggests that if we want to understand $\mathrm{CO}_{2}$ emissions from river systems, floodplains are a pivotal component to consider, as increases in $\mathrm{CO}_{2}$ emissions originate for $45 \%$ from terrestrial vegetation litter delivery to floodplains/wetlands. This may be higher for tropical floodplains, as floodplains/wetlands contribute relatively much to the total water area of river basins.

Our results show that improvement in some model formulations could result in a better match of simulations with observations. Firstly, a better description of the hydrology in low-order streams to replace the current parameterization will improve our C cycle model in headwaters. The HydroSheds dataset (Lehner and Grill, 2013) is a good candidate to improve our PCRGLOBWB model. The HydroLakes dataset (Messager et al., 2016) will improve the current data on lake and reservoir water volume. Secondly, $\mathrm{C}$ inputs are an important source of uncertainty in terms of their spatial distribution, organic/inorganic ratios and form (dissolved or particulate). For example, an improved estimate of terrestrial $P O C$ input from litterfall and its variation between headwaters to wider mainstreams is necessary to provide a more robust quantification and spatial estimate of $\mathrm{CO}_{2}$ 
https://doi.org/10.5194/gmd-2019-205

Preprint. Discussion started: 17 September 2019

(c) Author(s) 2019. CC BY 4.0 License.

(c) (i)

emissions from freshwaters. Similarly, alkalinity input from groundwater is important but uncertain and can be improved by a better model for weathering and $D O C$ input to aquifers and transformation to DIC. Finally, the modelled primary production is limited by light and carbon. A future major challenge to be tackled in global biogeochemical modelling frameworks is to introduce limitations to primary production imposed by nutrients (nitrogen, phosphorus and silicium) and oxygen availability.

\section{Code and data availability}

510 The presented version of CARBON-DISC is archived on Zenodo (van Hoek et al., 2019) under the Gnu Public License, GPL v3, in the form of input data and scripts to run the model and the raw output data for all the simulations presented in this study. Python scripts containing the source code of CARBON-DISC 1.0 are available in section A (source code). All used input data is found in section B (model input). Raw output data for the model runs shown in the results section are found in section $\mathrm{C}$ (raw output data). Data specifically to reproduce the figures are found in section D (data for figures). For further information

515 about the IMAGE-DGNM framework and the data used to produce the presented results, please contact Alexander F. Bouwman (lex.bouwman@pbl.nl).

\section{Author contributions}

W.J. van Hoek prepared the original draft, developed the CARBON-DISC module and ran the model simulations. A.H.W.

520 Beusen and J.M. Mogollón integrated the IMAGE-GNM and PCR-GLOBWB to construct the IMAGE-DGNM framework in which the CARBON-DISC was developed. J.J. Middelburg, A.F. Bou wman, L. Vilmin, X. Liu and J.J. Langeveld contributed to formulate concepts and research aims.

\section{Competing interests}

525 The authors declare that they have no conflict of interest.

\section{Acknowledgements}

This work is part of The New Delta 2014 ALW project project nr 869.15.014, which is financed by the Netherlands Organisation for Scientific Research (NWO). Alexander F. Bouwman and Arthur H. W. Beusen received support from PBL 530 Netherlands Environmental Assessment Agency through in-kind contributions to The New Delta 2014 ALW project. Lauriane Vilmin received funding from part of the Earth and life sciences (ALW) Open Programme 2016 project no. ALWOP.230, which is financed by the Netherlands Organisation for Scientific Research (NWO). Joep J. Langeveld received funding from The New Delta 2014 ALW project project nr 869.15.015, which is financed by the Netherlands Organisation for Scientific Research (NWO). 
https://doi.org/10.5194/gmd-2019-205

Preprint. Discussion started: 17 September 2019

(c) Author(s) 2019. CC BY 4.0 License.

(c) (i)

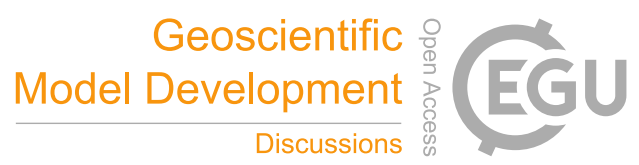

\section{References}

Abril, G., Bouillon, S., Darchambeau, F., Teodoru, C. R., Marwick, T. R., Tamooh, F., Ochieng Omengo, F., Geeraert, N., Deirmendjian, L., Polsenaere, P. and Borges, A. V.: Technical note: Large overestimation of pCO2 calculated from pH and alkalinity in acidic, organic-rich freshwaters, Biogeosciences, 12(1), 67-78, doi:10.5194/bg-12-67-2015, 2015.

540 Aitkenhead, J. A. and McDowell, W. H.: Soil C: N ratio as a predictor of annual riverine DOC flux at local and global scales, Global Biogeochem. Cycles, 14(1), 127-138, 2000.

Alin, S. R., Rasera, M. D. F. F. L., Salimon, C. I., Richey, J. E., Holtgrieve, G. W., Krusche, A. V. and Snidvongs, A.: Physical controls on carbon dioxide transfer velocity and flux in low-gradient river systems and implications for regional carbon budgets, J. Geophys. Res. Biogeosciences, 116(1), doi:10.1029/2010JG001398, 2011.

545 Bastviken, D., Tranvik, L. J., Downing, J. A., Crill, P. M. and Enrich-Prast, A.: Freshwater methane emissions offset the continental carbon sink, Science (80-. )., 331(6013), 50, 2011.

Batjes, N. H.: Revised soil parameter estimates for the soil types of the world, Soil Use Manag., 18(3), 232-235, doi:10.1079/SUM2002125, 2002.

Batjes, N. H.: Harmonized soil property values for broad-scale modelling (WISE30sec) with estimates of global soil carbon stocks, Geoderma, 269, 61-68, 2016.

Battin, T. J., Luyssaert, S., Kaplan, L. A., Aufdenkampe, A. K., Richter, A. and Tranvik, L. J.: The boundless carbon cycle, Nat. Geosci., 2(9), 598-600, 2009.

Van Beek, L. P. H., Wada, Y. and Bierkens, M. F. P.: Global monthly water stress: 1. Water balance and water availability, Water Resour. Res., 47(7), 2011.

555 Beusen, A. H. W., Dekkers, A. L. M., Bouwman, A. F., Ludwig, W. and Harrison, J.: Estimation of global river transport of sediments and associated particulate C, N, and P, Global Biogeochem. Cycles, 19(4), 2005.

Beusen, A. H. W., Van Beek, L. P. H., Bouwman, L., Mogollón, J. M. and Middelburg, J. B. M.: Coupling global models for hydrology and nutrient loading to simulate nitrogen and phosphorus retention in surface water-description of IMAGE-GNM and analysis of performance, Geosci. Model Dev., 8(12), 4045-4067, 2015.

560 Bianchi, T. S.: The role of terrestrially derived organic carbon in the coastal ocean: A changing paradigm and the priming effect, Proc. Natl. Acad. Sci., 108(49), 19473-19481, doi:10.1073/pnas.1017982108, 2011.

Borges, A. V., Abril, G., Darchambeau, F., Teodoru, C. R., Deborde, J., Vidal, L. O., Lambert, T. and Bouillon, S.: Divergent biophysical controls of aquatic CO2and CH4in the World's two largest rivers, Sci. Rep., 5, 1-10, doi:10.1038/srep15614, 2015.

565 Cerdan, O., Govers, G., Le Bissonnais, Y., Van Oost, K., Poesen, J., Saby, N., Gobin, A., Vacca, A., Quinton, J., Auerswald, K., Klik, A., Kwaad, F. J. P. M., Raclot, D., Ionita, I., Rejman, J., Rousseva, S., Muxart, T., Roxo, M. J. and Dostal, T.: Rates and spatial variations of soil erosion in Europe: A study based on erosion plot data, Geomorphology, 122(1-2), 167-177, doi:10.1016/j.geomorph.2010.06.011, 2010. 
https://doi.org/10.5194/gmd-2019-205

Preprint. Discussion started: 17 September 2019

(c) Author(s) 2019. CC BY 4.0 License.

(c) (i)

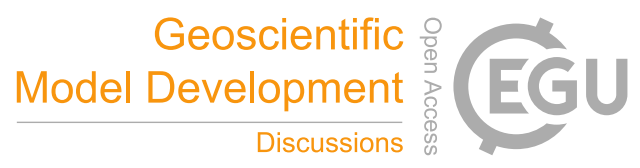

Ciais, P., Sabine, C., Bala, G., Bopp, L., Brovkin, V., Canadell, J., Chhabra, A., DeFries, R., Galloway, J. and Heimann, M.:

Carbon and other biogeochemical cycles, in Climate Change 2013: The Physical Science Basis. Contribution of Working

Group I to the Fifth Assessment Report of the Intergovernmental Panel on Climate Change, pp. 465-570, Cambridge University Press., 2013.

Cole, Prairie, Y. T., Caraco, N. F., McDowell, W. H., Tranvik, L. J., Striegl, R. G., Duarte, C. M., Kortelainen, P., Downing, J. A. and Middelburg, J. J.: Plumbing the global carbon cycle: integrating inland waters into the terrestrial carbon budget,

Ecosystems, 10(1), 172-185, 2007.

Crawford, J. T., Striegl, R. G., Wickland, K. P., Dornblaser, M. M. and Stanley, E. H.: Emissions of carbon dioxide and methane from a headwater stream network of interior Alaska, J. Geophys. Res. Biogeosciences, 118(2), 482-494, doi:10.1002/jgrg.20034, 2013.

Crawford, J. T., Loken, L. C., Stanley, E. H., Stets, E. G., Dornblaser, M. M. and Striegl, R. G.: Basin scale controls on CO2 and CH4 emissions from the Upper Mississippi River, Geophys. Res. Lett., 1-7, doi:10.1002/2015GL067599.Received, 2016.

Duarte, C. M. and Prairie, Y. T.: Prevalence of heterotrophy and atmospheric CO2 emissions from aquatic ecosystems, Ecosystems, 8(7), 862-870, doi:10.1007/s10021-005-0177-4, 2005.

Dürr, H. H., Meybeck, M. and Dürr, S. H.: Lithologic composition of the Earth's continental surfaces derived from a new digital map emphasizing riverine material transfer, Global Biogeochem. Cycles, 19(4), 1-23, doi:10.1029/2005GB002515, 5852005 .

Frankignoulle, M., Abril, G., Borges, A., Bourge, I., Canon, C., Delille, B., Libert, E. and Théate, J.-M.: Carbon Dioxide Emission from European Estuaries, Science (80-. )., 282(5388), 434-436, doi:10.1126/science.282.5388.434, 1998.

Garnier, J., Billen, G. and Palfner, L.: Understanding the oxygen budget and related ecological processes in the river Mosel: The RIVERSTRAHLER approach, Hydrobiologia, 410, 151-166, doi:10.1023/A:1003894200796, 2000.

590 Hartmann, J., Lauerwald, R. and Moosdorf, N.: A Brief Overview of the GLObal RIver Chemistry Database, GLORICH, Procedia Earth Planet. Sci., 10, 23-27, doi:10.1016/j.proeps.2014.08.005, 2014.

Hernes, P. J., Dyda, R. Y. and McDowell, W. H.: Connecting tropical river DOM and POM to the landscape with lignin, Geochim. Cosmochim. Acta, 219, 143-159, doi:10.1016/j.gca.2017.09.028, 2017.

van Hoek, W. J., Vilmin, L., Beusen, A., J., M., Langeveld, J., Bouwman, A. F. and Middelburg, J. J.: Release version 1 of the 595 CARBON-Dynamic In Stream Chemistry model, , doi:10.5281/ZENODO.3402473, 2019.

Holgerson, M. A. and Raymond, P. A.: Large contribution to inland water $\mathrm{CO} 2$ and $\mathrm{CH} 4$ emissions from very small ponds, Nat. Geosci., 9(3), 222-226, doi:10.1038/ngeo2654, 2016.

Hotchkiss, E. R., Hall Jr, R. O., Sponseller, R. A., Butman, D., Klaminder, J., Laudon, H., Rosvall, M. and Karlsson, J.: Sources of and processes controlling CO2 emissions change with the size of streams and rivers, Nat. Geosci., 8(9), 696-699, 2015.

600 Jansen, N.: Chemical rock weathering as source of dissolved silica and sink of atmospheric CO2, Intitute Biogeochem. Mar. Chem., Dr rer. na, 125, 2010.

Kempe, S.: Sinks of the anthropogenically enhanced carbon cycle in surface fresh waters, J. Geophys. Res., 89(D3), 4657, 
https://doi.org/10.5194/gmd-2019-205

Preprint. Discussion started: 17 September 2019

(c) Author(s) 2019. CC BY 4.0 License.

doi:10.1029/JD089iD03p04657, 1984.

Kirk, J. T. O.: Light and photosynthesis in aquatic ecosystems, Third Edit., Cambridge University Press., 2011.

Kroeze, C., Bouwman, A. F. and Seitzinger, S. P.: Modeling global nutrient export from watersheds, Curr. Opin. Environ. Sustain., 4(2), 195-202, 2012.

Lauerwald, R., Hartmann, J., Moosdorf, N., Kempe, S. and Raymond, P. A.: What controls the spatial patterns of the riverine carbonate system? - A case study for North America, Chem. Geol., 337-338, 114-127, doi:10.1016/j.chemgeo.2012.11.011, 2013.

610 Lehner, B. and Grill, G.: Global river hydrography and network routing: Baseline data and new approaches to study the world's large river systems, Hydrol. Process., 27(15), 2171-2186, doi:10.1002/hyp.9740, 2013.

Liu, E., Yan, C., Mei, X., Zhang, Y. and Fan, T.: Long-term effect of manure and fertilizer on soil organic carbon pools in dryland farming in northwest China, PLoS One, 8(2), e56536, 2013.

Lobbes, J. M., Fitznar, H. P. and Kattner, G.: Biogeochemical characteristics of dissolved and particulate organic matter in

615 Russian rivers entering the Arctic Ocean, Geochim. Cosmochim. Acta, 64(17), 2973-2983, 2000.

Mayorga, E., Seitzinger, S. P., Harrison, J. A., Dumont, E., Beusen, A. H. W., Bouwman, A. F., Fekete, B. M., Kroeze, C. and van Drecht, G.: Global nutrient export from WaterSheds 2 (NEWS 2): model development and implementation, Environ. Model. Softw., 25(7), 837-853, 2010.

Mcdowell, W. H., Wood, T., Forest, B. E. and Thornton, W.: PODZOLIZATION : SOIL PROCESSES CONTROL DISSOLVED ORGANIC CARBON CONCENTRATIONS IN STREAM WATER' This study was conducted at the Hubbard, Soil Sci., 137(1), 23-32, 1984.

Messager, M. L., Lehner, B., Grill, G., Nedeva, I. and Schmitt, O.: Estimating the volume and age of water stored in global lakes using a geo-statistical approach, Nat. Commun., 7, 1-11, doi:10.1038/ncomms13603, 2016.

Middelburg, J. J.: A simple rate model for organic matter decomposition in marine sediments, Geochim. Cosmochim. Acta, 625 53(7), 1577-1581, doi:https://doi.org/10.1016/0016-7037(89)90239-1, 1989.

Middelburg, J. J.: Organic Matter is more than CH2O BT - Marine Carbon Biogeochemistry : A Primer for Earth System Scientists, edited by J. J. Middelburg, pp. 107-118, Springer International Publishing, Cham., 2019.

Mitchell, T. D. and Jones, P. D.: An improved method of constructing a database of monthly climate observations and associated high-resolution grids, Int. J. Climatol., 25(6), 693-712, doi:10.1002/joc.1181, 2005.

630 Moosdorf, N., Hartmann, J., Lauerwald, R., Hagedorn, B. and Kempe, S.: Atmospheric CO2consumption by chemical weathering in North America, Geochim. Cosmochim. Acta, 75(24), 7829-7854, doi:10.1016/j.gca.2011.10.007, 2011.

Orr, J. C. and Epitalon, J. M.: Improved routines to model the ocean carbonate system: Mocsy 2.0, Geosci. Model Dev., 8(3), 485-499, doi:10.5194/gmd-8-485-2015, 2015.

Prairie, Y. T. and Cole, J. J.: Carbon , Unifying Currency, Encycl. Inl. Waters, 2(December), 743-746, doi:http://dx.doi.org/10.1016/B978-012370626-3.00107-1, 2009.

Prairie, Y. T. and Duarte, C. M.: Direct and indirect metabolic $\mathrm{CO}_{2}$ release by humanity, Biogeosciences Discuss., 3(6), 1781- 
https://doi.org/10.5194/gmd-2019-205

Preprint. Discussion started: 17 September 2019

(c) Author(s) 2019. CC BY 4.0 License.

1789, doi:10.5194/bgd-3-1781-2006, 2006.

Raymond, P. A., Hartmann, J., Lauerwald, R., Sobek, S., McDonald, C., Hoover, M., Butman, D., Striegl, R., Mayorga, E. and Humborg, C.: Global carbon dioxide emissions from inland waters, Nature, 503(7476), 355-359, 2013.

Regnier, P., Friedlingstein, P., Ciais, P., Mackenzie, F. T., Gruber, N., Janssens, I. A., Laruelle, G. G., Lauerwald, R., Luyssaert, S. and Andersson, A. J.: Anthropogenic perturbation of the carbon fluxes from land to ocean, Nat. Geosci., 6(8), 597-607, 2013.

Richardson, D. C., Newbold, J. D., Aufdenkampe, A. K., Taylor, P. G. and Kaplan, L. A.: Measuring heterotrophic respiration rates of suspended particulate organic carbon from stream ecosystems, Limnol. Oceanogr. Methods, 11(5), 247-261, 2013.

Riesebell, U., Wolf-Gladrow, D. A. and Smetacek, V.: Carbon dioxide limitation of marine phytoplankton growth rates, Nature, 361, 249-251, 1993.

Saltelli, A.: Chan. K., Scott EM (ed.), Sensitivity Analysis, 2000.

Sawakuchi, H. O., Neu, V., Ward, N. D., Barros, M. D. L. C., Valerio, A., Gagne-maynard, W., Cunha, A. C., Fernanda, D., Diniz, J. E., Brito, D. C., Krusche, A. V and Richey, J. E.: Carbon dioxide emissions along the lower Amazon River, Front.

Mar. Sci., 4(March), 1-12, doi:10.3389/fmars.2017.00076, 2017.

Scheffer, M.: Ecology of shallow lakes, Springer., 2004.

Sitch, S., Smith, B., Prentice, I. C., Arneth, A., Bondeau, A., Cramer, W., Kaplan, J. O., Levis, S., Lucht, W. and Sykes, M. T.: Evaluation of ecosystem dynamics, plant geography and terrestrial carbon cycling in the LPJ dynamic global vegetation model, Glob. Chang. Biol., 9(2), 161-185, 2003.

655 Soetaert, K. and Herman, P. M. J.: A practical guide to ecological modelling: using R as a simulation platform, Springer Science \& Business Media., 2008.

Soetaert, K., Hofmann, A. F., Middelburg, J. J., Meysman, F. J. R. and Greenwood, J.: Reprint of "The effect of biogeochemical processes on pH,” Mar. Chem., 106(1), 380-401, doi:https://doi.org/10.1016/j.marchem.2007.06.008, 2007.

Stehfest, E., van Vuuren, D., Kram, T., Bouwman, L., Alkemade, R., Bakkenes, M., Biemans, H., Bouwman, A., den Elzen,

M., Janse, J., Lucas, P., van Minnen, J., Muller, C. and Prins, A. G.: Integrated Assessment of Global Environmental Change with IMAGE 3.0. Model description and policy applications. [online] Available from: http://www.pbl.nl/en/publications/integrated-assessment-of-global-environmental-change-with-IMAGE-3.0, 2014.

Stelzer, R. S., Heffernan, J. and Likens, G. E.: The influence of dissolved nutrients and particulate organic matter quality on microbial respiration and biomass in a forest stream, Freshw. Biol., 48(11), 1925-1937, doi:10.1046/j.13652427.2003.01141.x, 2003.

Strokal, M., Kroeze, C., Wang, M., Bai, Z. and Ma, L.: The MARINA model (Model to Assess River Inputs of Nutrients to seAs): Model description and results for China, Sci. Total Environ., 562, 869-888, doi:10.1016/j.scitotenv.2016.04.071, 2016. Sutanudjaja, E. H., Beek, R. van, Wanders, N., Wada, Y., Bosmans, J. H. C., Drost, N., Ent, R. J., De Graaf, I. E. M., Hoch, J. M. and Jong, K. de: PCR-GLOBWB 2: a 5 arcmin global hydrological and water resources model, Geosci. Model Dev., 11(6), 2429-2453, 2018. 
https://doi.org/10.5194/gmd-2019-205

Preprint. Discussion started: 17 September 2019

(c) Author(s) 2019. CC BY 4.0 License.

(c) (i)

Tranvik, L. J., Downing, J. A., Cotner, J. B., Loiselle, S. A., Striegl, R. G., Ballatore, T. J., Dillon, P., Finlay, K., Fortino, K., Knoll, L. B., Kortelainen, P. L., Kutser, T., Larsen, S., Laurion, I., Leech, D. M., McCallister, S. L., McKnight, D. M., Melack, J. M., Overholt, E., Porter, J. A., Prairie, Y., Renwick, W. H., Roland, F., Sherman, B. S., Schindler, D. W., Sobek, S., Tremblay, A., Vanni, M. J., Verschoor, A. M., von Wachenfeldt, E. and Weyhenmeyer, G. A.: Lakes and reservoirs as regulators of carbon cycling and climate, Limnol. Oceanogr., 54(6), 2298-2314, doi:10.4319/lo.2009.54.6_part_2.2298, 2009. Uehlinger, U., Wantzen, K. M., Leuven, R. S. E. W. and Arndt, H.: The Rhine River Basin., 2009.

Vilmin, L., Mogollón, J. M., Beusen, A. H. W. and Bouwman, A. F.: Forms and subannual variability of nitrogen and phosphorus loading to global river networks over the 20th century, Glob. Planet. Change, 163(February), 67-85, doi:10.1016/j.gloplacha.2018.02.007, 2018.

680 Vilmin, L., Mogollón, J. M., Beusen, A. H. W., van Hoek, W. J., Liu, X., Middelburg, J. J. and Bouwman, A. F.: Modelling process-based biogeochemical dynamics in surface freshwaters with the \{IMAGE-DGNM \} framework, Environ. Model. Softw., 2019.

Wallin, M. B., Grabs, T., Buffam, I., Laudon, H., Ågren, A., Öquist, M. G. and Bishop, K.: Evasion of CO2 from streams The dominant component of the carbon export through the aquatic conduit in a boreal landscape, Glob. Chang. Biol., 19(3), 685 785-797, doi:10.1111/gcb.12083, 2013.

Wanninkhof, R.: Relationship between wind speed and gas exchange over the ocean revisited, Limnol. Oceanogr. Methods, 12(JUN), 351-362, doi:10.4319/lom.2014.12.351, 2014.

van der Weijden, C. H. and Middelburg, J. J.: Hydrogeochemistry of the river rhine: long term a $\mathrm{n}$ d seasonal variability, elemental budgets, base levels a n d pollution, , 23(10), 1247-1266, 1989.

690 Wollheim, W. M., V??r??smarty, C. J., Bouwman, A. F., Green, P., Harrison, J., Linder, E., Peterson, B. J., Seitzinger, S. P. and Syvitski, J. P. M.: Global N removal by freshwater aquatic systems using a spatially distributed, within-basin approach, Global Biogeochem. Cycles, 22(2), 1-14, doi:10.1029/2007GB002963, 2008.

Wollheim, W. M., Stewart, R. J., Aiken, G. R., Butler, K. D., Morse, N. B. and Salisbury, J.: Removal of terrestrial DOC in aquatic ecosystems of a temperate river network, Geophys. Res. Lett., 42(16), 6671-6679, 2015. 
Table 1: Sources of $\mathrm{C}$ to surface waters as shown in fig. 03 and description of their calculation

\begin{tabular}{lll}
\hline source & description
\end{tabular}

$D O C$ input from Global organic carbon from waste is obtained from estimates by (Prairie and waste water $\left(W A S_{D O C}\right)$ Duarte, 2006) is combined with the spatio-temporal estimates of $\mathrm{P}$ in wastewater from Vilmin et al. (2018) to obtain DOC in waste water from (Vilmin et al., 2018). All organic carbon in waste water is assumed to be in dissolved form.

$D O C$ input from $D O C$ in soil moisture is transported to the oceans via rivers ((Mcdowell et surface runoff al., 1984; Aitkenhead and McDowell, 2000; Lobbes et al., 2000; Hernes et $\left(S R O_{D O C}\right)$ al., 2017). DOC in soil moisture enters surface freshwaters via surface runoff. $D O C$ in soil moisture is related to the soil organic carbon (fSOC) (Liu et al., 2013). The dissolved fraction of the total soil organic carbon is here assumed to $1 \%$. A spatial distribution of SOC is obtained from (Batjes, 2016). SOC [\%] is multiplied with bulk density $\left[\mathrm{kg} / \mathrm{dm}^{3}\right]$ ((Batjes, 2002), which gives the mass density of soil organic carbon $\left[\mathrm{kg} / \mathrm{dm}^{3}\right]$. Multiplication of the soil organic carbon mass density with monthly surface runoff from (Van Beek et al., 2011)

$P O C_{\text {terre }}$ input Soil erosion delivers terrestrial $P O C$ in freshwaters parallel to an approach from soil loss proposed by (Cerdan et al., 2010) based on slope, soil texture and land cover $\left(S O I_{P O C}\right)$ type. Country aggregated soil loss rates for arable land, grassland and natural vegetation were applied to all grid cells with each their own areal fraction of arable land, grassland and natural vegetation. The soil loss enters the surface 
waters as SPM. To account for the POC $_{\text {terre, }}$ SPM input is multiplied with fsoc from (Batjes, 2016) to obtain the $P P O C$ in eroded soil.

$P O C_{\text {terre }}$ input Terrestrial $P O C$ input from litterfall is based on IMAGE estimates of $\mathrm{C}$ from litterfall production with NPP for wetlands and floodplains from the LPJ model (LIT $P O C)$ (Sitch et al., 2003). In the DISC module, $P O C_{\text {terre }}$ from litterfall enters surface waters in two ways. 1: via riparian zones of small streams $50 \%$ of total NPP within the areal fraction of riparian zones (of 1 meter wide) is assumed to end in the stream 2: via floodplains along the mainstream $100 \%$ of total NPP within the floodplain area is considered to end up in the floodplain surface waters.

DIC/Alkalinity Lithology and discharge are the strongest controllers for annual bicarbonate input from fluxes for 338 catchments basin across North America. (Jansen, 2010; weathering Moosdorf et al., 2011; Lauerwald et al., 2013). Here we apply the empirical $\left(W E A_{D I C}\right)$ parameterization for annual bicarbonate fluxes from (Jansen, 2010). We use lithological data from (Dürr et al., 2005). All the DIC input from this source is assumed to be bicarbonate.

Table 2: Parameters, units, values and literature references

\begin{tabular}{llll}
\hline parameter & unit & value & reference \\
\hline C $_{\text {atmosphere }}$ & mmol L $^{-1}$ & 0.0136 & - \\
& & $(400 \mathrm{ppm})$ & \\
$a_{1}$ & - & 4.46 & (Alin et al., 2011) \\
$b_{1}$ & - & 7.11 & (Alin et al., 2011) \\
$a_{2}$ & - & 13.82 & (Alin et al., 2011) \\
$b_{2}$ & - & 0.35 & (Alin et al., 2011) \\
$k_{\text {DOCmin }}$ & day $^{-1}$ & 0.04 & (Richardson et al., 2013) \\
\hline
\end{tabular}




\begin{tabular}{|c|c|c|c|}
\hline$\eta_{\text {DOC }}$ & $\mathrm{m}^{-1} \mathrm{mg}^{-1} \mathrm{~L}$ & 0.01 & (Scheffer, 2004) \\
\hline$k_{P O C t e r r e \_m i n}$ & day $^{-1}$ & 0.01 & (Richardson et al., 2013) \\
\hline Q10 POCterre & - & 2 & (Soetaert and Herman, 2008) \\
\hline$\eta_{\text {POCterre }}$ & $\mathrm{m}^{-1} \mathrm{mg}^{-1} \mathrm{~L}$ & 0.05 & (Scheffer, 2004) \\
\hline vsedPOCterre & $\mathrm{km} \mathrm{yr}^{-1}$ & 4.38 & (Vilmin et al., 2019) \\
\hline$k_{\text {SEDOCterre_min }}$ & day $^{-1}$ & 0.001 & (Richardson et al., 2013) \\
\hline Q10 SEDOCterre & - & 2 & (Soetaert and Herman, 2008) \\
\hline$k_{P O C a u t o \_m i n}$ & day $^{-1}$ & 0.02 & (Richardson et al., 2013) \\
\hline Q10 POCauto & - & 2 & (Soetaert and Herman, 2008) \\
\hline$\eta_{\text {POCauto }}$ & $\mathrm{m}^{-1} \mathrm{mg}^{-1} \mathrm{~L}$ & 0.03 & (Scheffer, 2004) \\
\hline vsed $_{\text {POCauto }}$ & $\mathrm{km} \mathrm{yr}^{-1}$ & 4.38 & (Vilmin et al., 2019) \\
\hline$k_{\text {SEDOCauto_min }}$ & day $^{-1}$ & 0.02 & (Richardson et al., 2013) \\
\hline Q10 SEDOCauto & - & 2 & (Soetaert and Herman, 2008) \\
\hline$k_{\text {burial }}$ & day $^{-1}$ & 0.024 & - \\
\hline$k_{A L G \_p p}$ & day $^{-1}$ & 4.8 & (Garnier et al., 2000) \\
\hline$k_{I} A L G$ & $\mathrm{~W} \mathrm{~m}^{-2}$ & 25 & (Garnier et al., 2000) \\
\hline$k_{D I C \_A L G}$ & $\mathrm{mmol} \mathrm{L}^{-1}$ & 0.001 & (Riesebell et al., 1993) \\
\hline$k_{A L G \_r e s p}$ & day $^{-1}$ & 0.072 & (Garnier et al., 2000) \\
\hline$k_{A L G \_m o r t}$ & day $^{-1}$ & 0.096 & (Garnier et al., 2000) \\
\hline$k_{A L G \_e x c r}$ & day $^{-1}$ & 0.072 & (Garnier et al., 2000) \\
\hline$v f_{A L G}$ & - & 20 & (Garnier et al., 2000) \\
\hline \multicolumn{4}{|c|}{ (parasitic lysis amplification) } \\
\hline p_threshold $A L G$ & mmol C L ${ }^{-1}$ & 0.019 & (Garnier et al., 2000) \\
\hline$k_{A L G \_b e n t h \_p p}$ & day $^{-1}$ & 1.5 & (Garnier et al., 2000) \\
\hline$k_{I} A L G \_b e n t h$ & $\mathrm{~W} \mathrm{~m}^{-2}$ & 12.5 & (Garnier et al., 2000) \\
\hline$k_{D I C \_A L G \_b e n t h}$ & $\mathrm{mmol} \mathrm{L}^{-1}$ & 0.001 & (Riesebell et al., 1993) \\
\hline$k_{A L G \_b e n t h \_r e s p}$ & day $^{-1}$ & 0.072 & (Garnier et al., 2000) \\
\hline$k_{A L G \_b e n t h \_m o r t}$ & day $^{-1}$ & 0.096 & (Garnier et al., 2000) \\
\hline
\end{tabular}




\begin{tabular}{|c|c|c|c|}
\hline$k_{A L G \_b e n t h \_e x c r}$ & day $^{-1}$ & 0.072 & (Garnier et al., 2000) \\
\hline $\begin{array}{l}v f_{A L G \_b e n t h} \\
\text { (parasitic lysis amplification) }\end{array}$ & - & 20 & (Garnier et al., 2000) \\
\hline p_threshold ${ }_{A L G \_b e n t h}$ & $\mathrm{mmol} \mathrm{C} \mathrm{L}{ }^{-1}$ & 0.019 & (Garnier et al., 2000) \\
\hline
\end{tabular}

Table 3: Model parameters and units

\begin{tabular}{|c|c|}
\hline parameter & meaning \\
\hline$W A S_{D O C}$ & dissolved organic carbon in waste water $\left[\mathrm{Mmol} \mathrm{yr}^{-1}\right]$ \\
\hline LIT $_{\text {POCterre }}$ & particulate organic carbon in litterfall $\left[\mathrm{Mmol} \mathrm{yr}^{-1}\right]$ \\
\hline$W E A_{D I C}$ & dissolved organic carbon in weathering $\left[\mathrm{Mmol} \mathrm{yr}^{-1}\right]$ \\
\hline SOIPOCterre & particulate organic carbon in soil loss $\left[\mathrm{Mmol} \mathrm{yr}^{-1}\right]$ \\
\hline$L E A_{D O C}$ & dissolved organic carbon in soil leaching water $\left[\mathrm{Mmol} \mathrm{yr}^{-1}\right]$ \\
\hline$W A S_{D O C}$ & dissolved organic carbon in waste water $\left[\mathrm{Mmol} \mathrm{yr}^{-1}\right]$ \\
\hline fDOC & mass fraction of dissolved organic carbon $[-]$ \\
\hline fSOC & mass fraction of soil organic carbon $[-]$ \\
\hline$\rho_{b}$ & soil dry bulk density $\left[\mathrm{kg} \mathrm{dm}^{-3}\right]$ \\
\hline soil $_{\text {ro }}$ & soil runoff $\left[\mathrm{mm} \mathrm{yr}^{-1}\right]$ \\
\hline$T S S$ & total suspended solids [Mmol] \\
\hline$N P P$ & 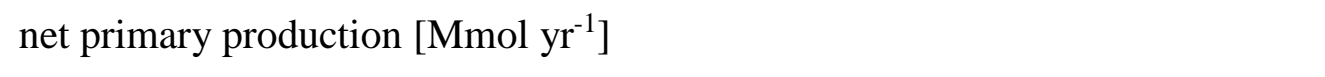 \\
\hline$f_{\text {wetlands }}$ & areal fraction of wetlands $[-]$ \\
\hline$f_{\text {floodplains }}$ & areal fraction of floodplains [-] \\
\hline$b_{0}$ & empirical parameter used to calculate alkalinity discharge \\
\hline$A_{L}$ & area with lithological class $\mathrm{L}\left[\mathrm{km}^{2}\right]$ \\
\hline$Q$ & discharge $\left[\mathrm{km}^{3} \mathrm{yr}^{-1}\right]$ \\
\hline$b_{L}$ & $\begin{array}{l}\text { empirical parameter accounting for effect of lithological class L on alkalinity } \\
\text { discharge }\end{array}$ \\
\hline $\mathrm{v}$ & flow velocity in order $I_{[}\left[\mathrm{cm} \mathrm{s}^{-1}\right]$ \\
\hline
\end{tabular}




\begin{tabular}{|c|c|}
\hline $\mathrm{A}_{\mathrm{b}}$ & stream bed area $\left[\mathrm{km}^{2}\right]$ \\
\hline $\mathrm{D}$ & stream depth $[\mathrm{m}]$ \\
\hline $\mathrm{w}$ & stream width $[\mathrm{m}]$ \\
\hline $\mathrm{u}_{10}$ & windspeed at 10 meters above water surface $\left[\mathrm{m} \mathrm{s}^{-1}\right]$ \\
\hline$F_{\text {high_veg }}$ & high vegetation fraction \\
\hline$F_{\text {ulo_veg }}$ & wind speed reduction under high vegetation \\
\hline k600 & Gas exchange rate at $20^{\circ} \mathrm{C}\left[\mathrm{cm} \mathrm{h}^{-1}\right]$ \\
\hline $\mathrm{Sc}_{\mathrm{T}}$ & Schmidt number for temperature $\mathrm{T}$ \\
\hline$\eta$ & parameter to represent the effect of a biogeochemical specie on light extinction \\
\hline & in the water column \\
\hline $\mathrm{T}$ & water temperature $\left[{ }^{\circ} \mathrm{C}\right]$ \\
\hline $\mathrm{I}_{0}$ & solar radiation at water surface $\left[\mathrm{W} \mathrm{m}^{-2}\right]$ \\
\hline $\mathrm{I}_{\mathrm{z}}$ & light at depth $\mathrm{z}$ in the water column $\left[\mathrm{W} \mathrm{m}^{-2}\right]$ \\
\hline k_I & half saturation for light limitation with Michaelis-Menten $\left[\mathrm{W} \mathrm{m}^{-2}\right]$ \\
\hline k_DIC & half saturation for DIC limitation with Michaelis-Menten $\left[\mathrm{mmol} \mathrm{L}^{-1}\right]$ \\
\hline
\end{tabular}

Table 4: SRC values of most relevant parameters and results obtained from the sensitivity analysis. In green the most important positive SRC's, in red the most important negative SRC's.

\begin{tabular}{|c|c|c|c|c|c|c|c|c|}
\hline & \multicolumn{6}{|c|}{$\mathrm{CO}_{2}$ exchange } & $\mathbf{T C}$ & POC \\
\hline parameter & total & headwaters & $\begin{array}{c}\text { main } \\
\text { stream }\end{array}$ & lakes & reservoirs & floodplains & export & retention \\
\hline Q & -0.01 & -0.06 & -0.11 & -0.18 & -0.11 & 0.06 & 0.34 & -0.06 \\
\hline $\mathrm{T}$ & 0.27 & & 0.04 & 0.11 & 0.08 & 0.32 & -0.07 & -0.50 \\
\hline $\mathrm{I}_{0}$ & -0.24 & & -0.08 & -0.04 & -0.07 & -0.28 & 0.10 & 0.03 \\
\hline$k_{\text {SEDOCterre_min }}$ & 0.28 & & 0.03 & 0.04 & 0.05 & 0.34 & -0.02 & -0.36 \\
\hline$k_{\text {sedbur }}$ & -0.22 & & -0.02 & -0.03 & -0.05 & -0.28 & 0.02 & 0.23 \\
\hline$k_{\text {sedlim }}$ & 0.16 & & 0.01 & 0.01 & 0.02 & 0.21 & -0.02 & -0.15 \\
\hline$W E A_{D I C}$ & 0.43 & 0.72 & 0.71 & 0.69 & 0.69 & 0.07 & 0.01 & \\
\hline$W E A_{A L K}$ & -0.42 & -0.70 & -0.68 & -0.67 & -0.67 & -0.07 & 0.90 & \\
\hline$L_{P O C_{-} \text {floodplains }}$ & 0.45 & & 0.03 & 0.02 & & 0.57 & 0.09 & 0.55 \\
\hline
\end{tabular}

